\title{
p73 promotes glioblastoma cell invasion by directly activating POSTN (periostin) expression
}

\author{
Vivien Landré ${ }^{1}$, Alexey Antonov ${ }^{1}$, Richard Knight ${ }^{1}$ and Gerry Melino ${ }^{1,2}$ \\ ${ }^{1}$ Medical Research Council Toxicology Unit, Leicester LE1 9HN, UK \\ 2 University of Rome Tor Vergata, 00133-Rome, Italy \\ Correspondence to: Gerry Melino, email: gm89@le.ac.uk
}

Keywords: periostin, p53 family, cell death, temozolomide, metastasis

Received: September 29, 2015 Accepted: January 18, $2016 \quad$ Published: February 22, 2016

\section{ABSTRACT}

\begin{abstract}
Glioblastoma Multiforme is one of the most highly metastatic cancers and constitutes $\mathbf{7 0} \%$ of all gliomas. Despite aggressive treatments these tumours have an exceptionally bad prognosis, mainly due to therapy resistance and tumour recurrence. Here we show that the transcription factor p73 confers an invasive phenotype by directly activating expression of POSTN (periostin, HGNC:16953) in glioblastoma cells. Knock down of endogenous p73 reduces invasiveness and chemo-resistance, and promotes differentiation in vitro. Using chromatin immunoprecipitation and reporter assays we demonstrate that POSTN, an integrin binding protein that has recently been shown to play a major role in metastasis, is a transcriptional target of TAp73. We further show that POSTN overexpression is sufficient to rescue the invasive phenotype of glioblastoma cells after p73 knock down. Additionally, bioinformatics analysis revealed that an intact p73/ POSTN axis, where POSTN and p73 expression is correlated, predicts bad prognosis in several cancer types. Taken together, our results support a novel role of TAp73 in controlling glioblastoma cell invasion by regulating the expression of the matricellular protein POSTN.
\end{abstract}

\section{INTRODUCTION}

Glioblastoma Multiforme (GBM) is the most common malignant brain tumour in adult patients with an extremely poor prognosis of only 15 month median survival after diagnosis [1]. Despite aggressive treatment, usually consisting of tumour resection followed by radiation- and chemotherapy, tumour recurrence and therapeutic resistance is exceptionally common, making these tumours de facto incurable [2-6].

Several studies over the last decade have suggested that GBM develops from a subsection of tumour cells called stem-like glioblastoma cells [7-9]. These cells, characterised by a self-renewing, often chemoresistant and immature differentiation phenotype, have tumour-initiating properties and are largely believed to be responsible for tumour recurrence and therapeutic resistance. Even single cells that survive therapy have the ability to initiate growth of a new tumour, and are therefore also called tumour-seeding cells $[2,10]$. This suggests that differentiation therapies that induce cancer stem-cell differentiation would be a promising approach to target GBM [11-13]. While differentiation therapy is successfully used to treat acute promyeloctic leukaemia, where it leads to a dramatic increase of patient survival [14], no drug that induces differentiation in solid tumours has yet been developed. This is mainly due to a lack of development-based classification of these tumours, which often have considerably more varied genetic abnormalities compared to acute promyeloctic leukaemia, as well as our limited understanding of the pathways and components involved in the differentiation of different cancer types [14].

The transcription factor p73 is a member of the p53 family, which comprises three members p53, p63 and p73 that share similarities in their structure and function [15-19]. Having been discovered already in 1979, p53 is the most studied component of this family of transcription factors, showing a very complex gene activation program spanning from autophagy $[20,21]$, ROS, metabolism and mitochondria regulation [22-24], DNA damage response [25-29] to stemness and lineage determination [30-32]. Despite 35 years of high quality research, several crucial issues remain unanswered 
in order to fully understand the biological role and function of this tumour suppressor. In fact p53, as well as its family members, shows an extreme complexity, including, for example, its stability and degradation [3337 , its connection and regulation to micro-RNA [38$44]$ and its splicing isoforms $[45,46]$. In parallel to the advances in p53 biology, crucial progress is also under way for its therapeutic exploitation [47-56]. Although having been identified much later, p63 and p73 already show their complexity and interaction with p53 [57-63]; where p63 function is highly relevant in skin formation and homeostasis [64] as well as in cancer $[63,65,66]$. p73 exists in a variety of isoforms which can be divided into transactivation (TA) domain containing isoforms (TAp73) and those lacking the TA domain $(\Delta \mathrm{Np} 73)$, and each of these can be expressed as a number of $\mathrm{C}$-terminal isoforms to exert distinct functions [67-74]. Depending on cell type and p73 isoform, the protein has been shown to exhibit both tumour suppressive and oncogenic functions [7577]. Unlike p53, p73 is rarely mutated in human cancers and both the TA and $\Delta \mathrm{N}$ isoforms have been shown to be overexpressed in several tumour types [78, 79]. p73 deficient mice have striking developmental deficiencies in the CNS, mainly characterised by cortical loss leading to ex vacuo hydrocephalus as well as dysgenesis of the hippocampus and caudal cortex [80, 81]. Interestingly, these severe neurological deficiencies are phenocopied neither by the $\Delta \mathrm{Np} 73$ nor the TAp $73 \mathrm{KO}$ mice, suggesting redundancy of the two isoforms during neurogenesis [82]. TAp73 KO mice display several abnormalities in the hippocampus, while $\Delta \mathrm{Np} 73 \mathrm{KO}$ mice are healthy and show a relatively mild neurological phenotype with loss of the hydrocephalus, but no cortical loss [83-85].

Here we demonstrate that p73 plays a role in glioblastoma cell differentiation, since loss of p73 in glioblastoma cells leads to a more differentiated phenotype with reduced migration and invasion abilities. Furthermore, we show that the extracellular protein POSTN (periostin, osteoblast specific factor, HGNC:16953), that has been shown to play a role in glioblastoma carcinogenesis and is an important factor in metastasis, is transcriptionally activated by $\mathrm{p} 73$, and that this activation leads to increased cell invasion of glioblastoma cells in vitro.

\section{RESULTS}

\section{Loss of p73 leads to glioblastoma cell differentiation}

Although the role of p73 in neuronal development and differentiation has been studied extensively in recent years, relatively little attention has been paid to its role in the development and metastasis of malignancies originating in the brain. Several studies in GBM [8688] revealed a correlation between mRNA levels of the TAp73 and $\Delta \mathrm{Np} 73$ isoforms and tumour grade as well as patient survival, leading to the suggestion that $\mathrm{p} 73$ may be a potential biomarker of GBM tumour grade. Furthermore, analysis of datasets of glioma patients showed a correlation between p73 gene deletion and longer survival (Figure 1A). Therefore, as a first step to understand the potential mechanism for this correlation, we knocked down total p73 mRNA using siRNA in the U251 and U87 glioblastoma cell lines (Figures 1B, S1, S2A). Strikingly, p73 knock down resulted in a dramatic change of cell morphology, from a flat polygonal shape to a small, round cell body with very long and fine processes, an appearance, which resembles that of mature astrocytes. To further demonstrate that the change in morphology is due to cell differentiation, glioblastoma cells, transfected with control siRNA or siRNA specific for total p73, were stained using a GFAP (glial fibrillary acidic protein) antibody (Figures 1C, S2B). GFAP is an intermediate filament that is highly expressed in differentiated astrocytes. The GFAP signal in the cell processes was quantified, and the results showed that GFAP expression is higher in the cells in which p73 had been knocked down (Figure 1C, right panel). This observation suggests that glioblastoma cells may differentiate into astrocytes in the absence of $\mathrm{p} 73$. This is also in line with previous studies published by our group showing a decrease in stemness markers in neurons isolated from p $73 \mathrm{KO}$ compared to $\mathrm{wt}$ mice [89] and reduced Nestin expression, a neuronal stem cell marker, in the dentate gyrus of p73 KO mice [90].

As these results suggest a role of p73 in regulating the differentiation status of glioblastoma cells, we were interested in the effect of induced differentiation on p73 protein levels. To study this, differentiation of glioblastoma cells was induced by serum withdrawal (Figure 1E, 1F) and p73 levels were determined by western blotting (Figure 1D). Serum withdrawal led to almost complete loss of $\mathrm{p} 73$ protein expression, while no change in p73 protein levels was seen when serum was replaced by growth factors and supplements promoting stem-cell-like properties [91].

\section{p73 regulates cell migration and invasion}

The fact that stem-like glioblastoma cells are generally associated with a mesenchymal phenotype, and that $\mathrm{p} 73$ affects the differentiation status of glioblastoma cells, suggests that p73 can affect epithelial to mesenchymal transition (EMT). We therefore performed western blot analysis of different EMT markers after total p73 knock down. As shown in Figure 2A (and S3A), transient knock down of $\mathrm{p} 73$ led to a remarkable reduction of SNAIL, an important factor in the delamination process in neuronal tissue development, together with up-regulation of E-cadherin [92, 93]. We observed no 
A)

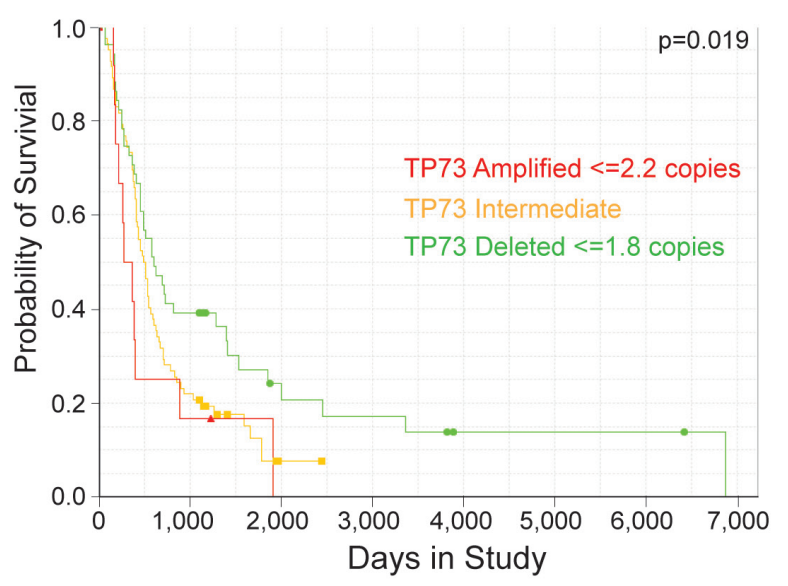

C)

si RNA:
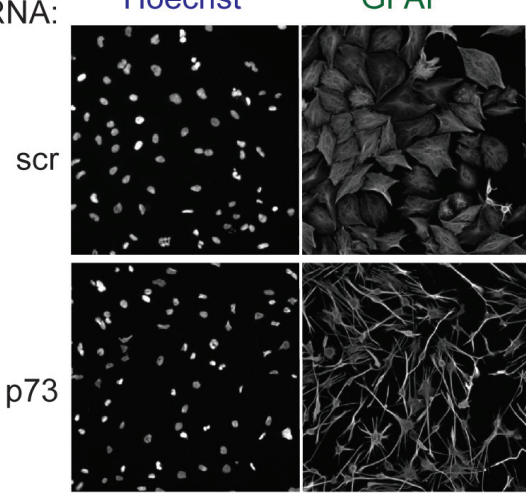

p73

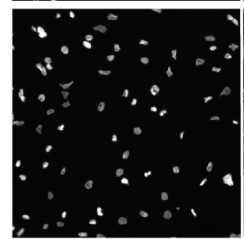

E)

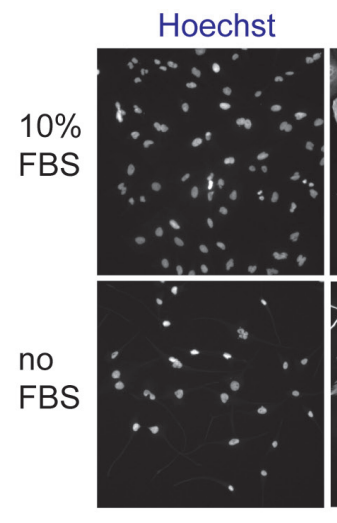

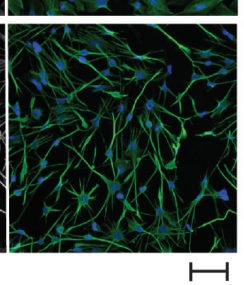

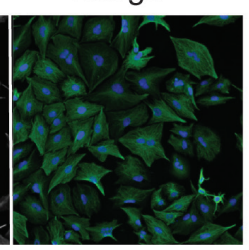

B)

si scr

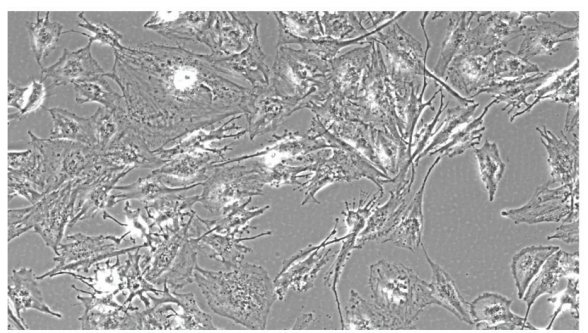

si $p 73$

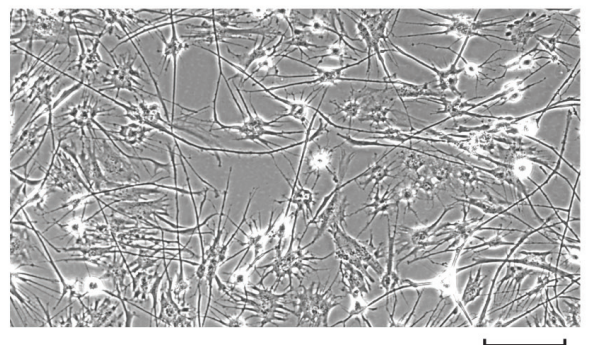

D)
Serum + - -

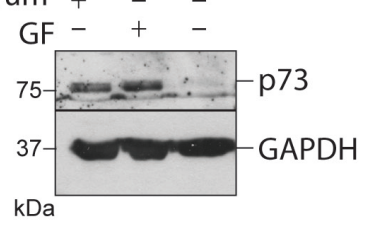

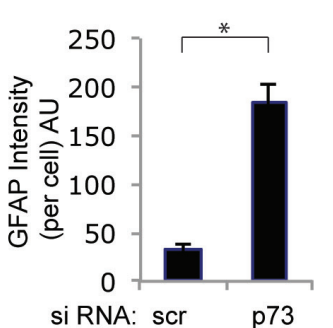

F)

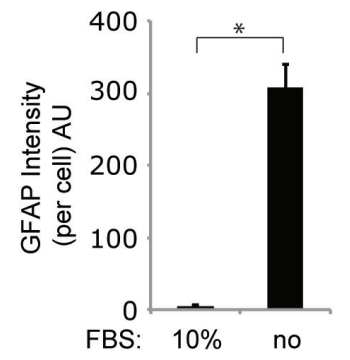

Figure 1: P73 knock down induces morphological transformation of glioblastoma cells. A. p73 gene deletion is correlated with prolonged survival of glioblastoma patients. Data is from the REMBRANT database/NIH (https://caintegrator.nci.nih.gov/rembrandt/). The $p$-value corresponds to the gene deletion group in comparison to all other patients. B. Morphological changes of U251 cells after $72 \mathrm{~h}$ of p73 knock down using siRNA transfection. C. Cells as in B but fixed and stained with an anti-GFAP antibody. Pictures were taken using the Cellomics, GFAP signal was quantified and is expressed as arbitrary units (right panel). D. Cells were grown in media that was serum rich (10\%), serum free or media complemented with growth factors (GF) (20 ng/ml EGF and FGF) and p27 supplement. Total protein was extracted and blotted with antibodies against p73 and GAPDH. E. Cells were incubated in serum free medium or full medium for $72 \mathrm{~h}$ and visualised and quantified (F) using a GFAP antibody as in C. Scale Bars in B, C and E represent $100 \mu \mathrm{m} .{ }^{*} p<0.0001$. Error bars represent SEM. 
change in other EMT marker i.e. Twist and Vimentin (data not shown). EMT is generally associated with an invasive phenotype, and we therefore wanted to establish whether p73 affects the migration and/or invasion ability

A)
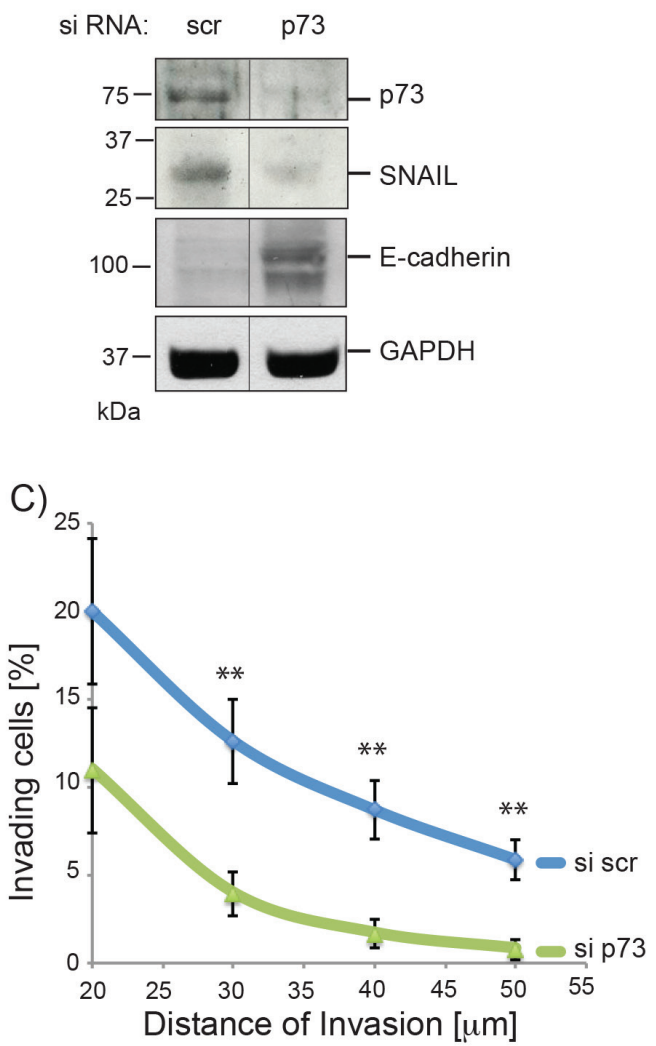

D)

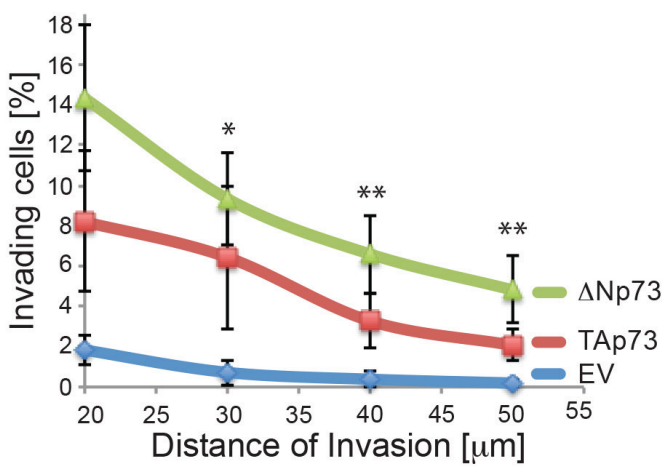

TAp73

$\triangle \mathrm{Np} 73$ of glioblastoma cells. Cell migration was assayed using the xCELLigence system, whereby cells that migrated through a membrane, from serum free towards serum containing media, were quantified. The assay showed a
B)
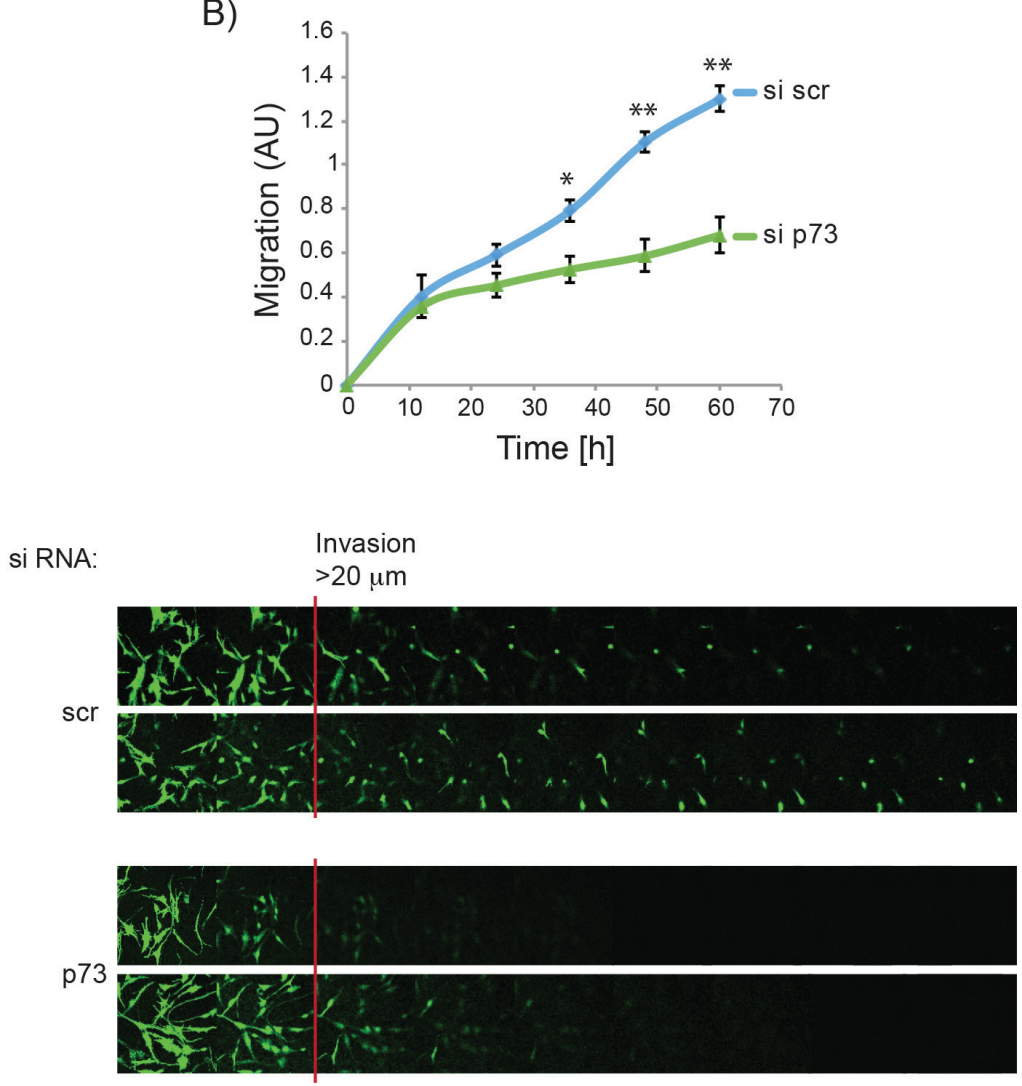

Invasion

$>20 \mu \mathrm{m}$

EV
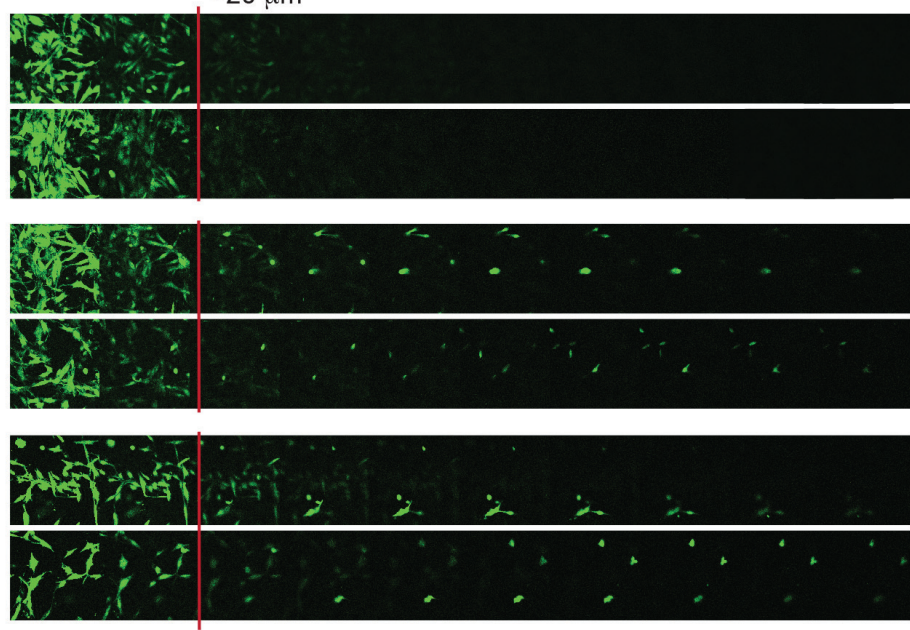

Figure 2: P73 knock down reduces migration and invasion of glioblastoma cells. A. Whole protein extract of U251 cells 72 $\mathrm{h}$ post-transfection with scr or p73 siRNA was analysed by immunoblotting with antibodies against p73, SNAIL, E-cadherin and GAPDH. Line indicates where 2 lanes that are not next to each other on the gel were moved side by side (see Figure S3A for full scan). B. The migration ability of U251 cells after siRNA transfection (scr or p73) was determined using the xCelligence. C. Invasion into matrigel of U251 cells that were transfected with siRNAs targeting p73 or a non-targeting control is shown. D. As in C but cells were transiently transfected with plasmids encoding TAp $73 \alpha, \Delta \mathrm{Np} 73 \alpha$ or empty vector control. $P$-values shown are for EV compared to TAp73 and EV compared $\Delta$ Np73. ${ }^{*} p<0.1, * * p<0.05$. Error bars represent SEM. 
striking reduction in cell migration ability after knock down of p73 (Figure 2B). Similarly, in an invasion assay, where the ability of the cells to enter and invade a matrigel matrix was assessed, knock down of total p73 resulted in consistent reduction of invasion (Figure $2 \mathrm{C}$ ), whereas overexpression of p73 isoforms led to an increase in matrigel invasion (Figures 2D, S3B). Together these results demonstrate a role of $\mathrm{p} 73$ in glioblastoma cell morphology, associated with a more invasive phenotype.

To gain insight into the molecular mechanisms underlying these changes of U251 morphology and invasion, we performed a gene microarray analysis of U251 cells transfected with siRNA for total p73 or a scrambled sequence for $72 \mathrm{~h}$. We found 632 genes differentially expressed in the knock down compared to the control cells (Figure 3A). Using a pathway analysis tool [94], we identified the pathways most enriched in differentially expressed genes to be: Integrin binding, fibronectin binding, blood coagulation and cell adhesion (Figure 3A-3C). This molecular data is in agreement with the biological effect of p73 in cell migration, as integrin and fibronectin as well as cell adhesion pathways are all involved in cell mobility, and alterations of these pathways have been shown to be involved in metastasis of cancer cells [95]. To verify the results of the microarray we tested the expression of the top ten down- and seven up-regulated genes and found that we could validate $\sim 73 \%$ of the genes in the array (Figure S4).

B)

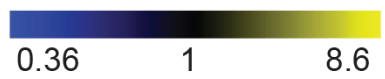

siRNA:

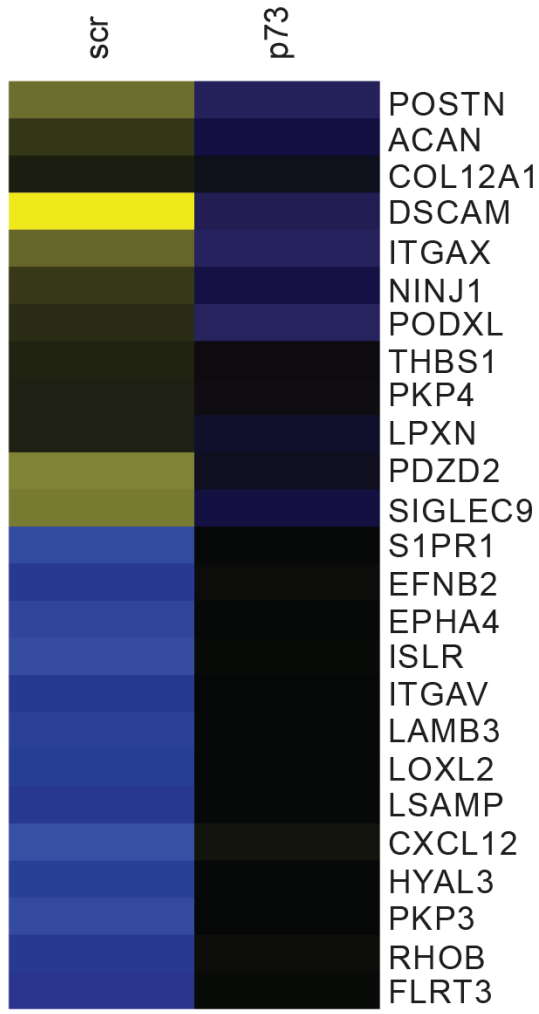

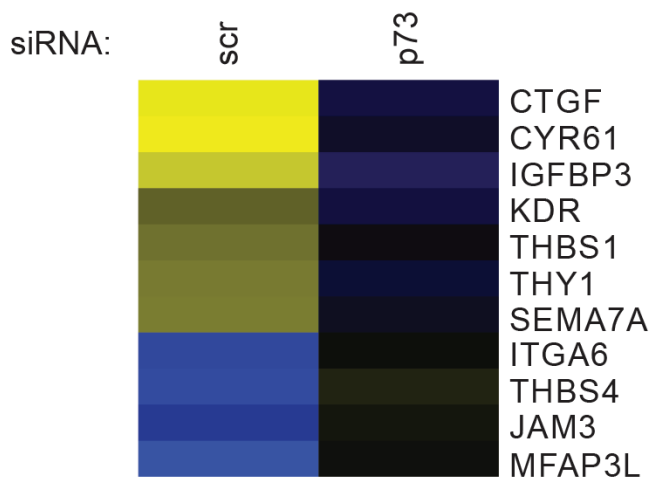

Figure 3: Analysis of mRNA expression after p73 knock down suggests a role for p73 in cell migration and invasion. A. Results of the microarray revealed 632 genes that were differentially expressed in control cells compared to knock down of endogenous p73 (Schematic illustration of gene array results). Pathway analysis of microarray results comparing U251 transfected with scr siRNA and p73 siRNA indicated changes in the pathways shown. Odds ratios for pathways are Integrin binding $=4.4$, Fibronectin binding 9.05 and Cell adhesion $=2.04$. p- values refer to the significance of enrichment of genes of the pathways shown. Heat maps of B. "Integrin and Fibronectin binding" (combined), 10 genes for integrin binding and 5 genes for fibronectin binding were identified, while CTGF is involved in both pathways. C. "Cell Adhesion" genes identified by GO term analysis, as differentially expressed between si scr and si p73. 
A)

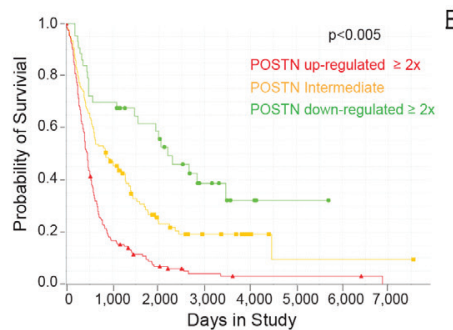

C)

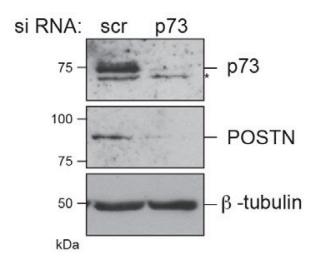

D)

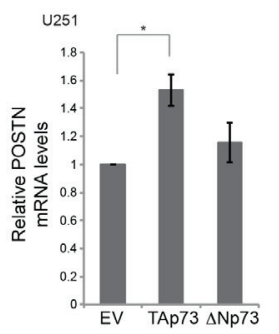

B)
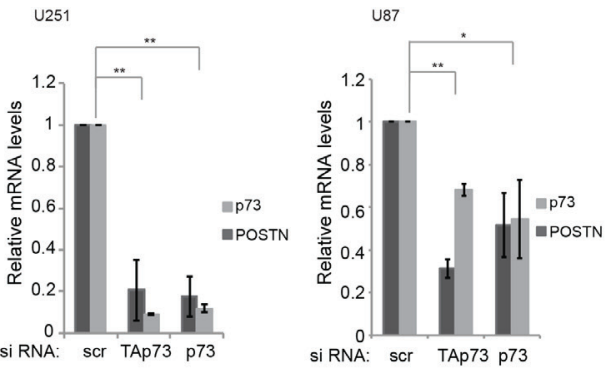

E)

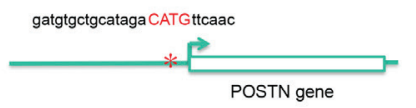

F)
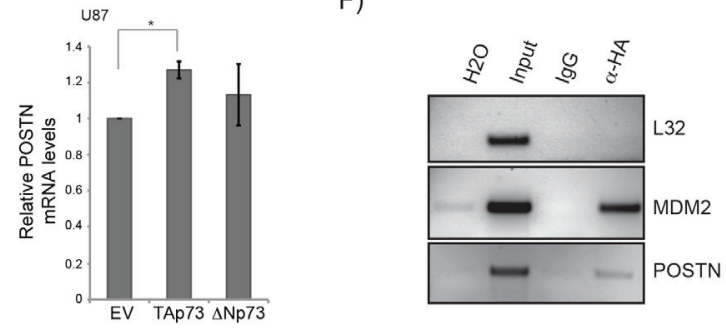

G)
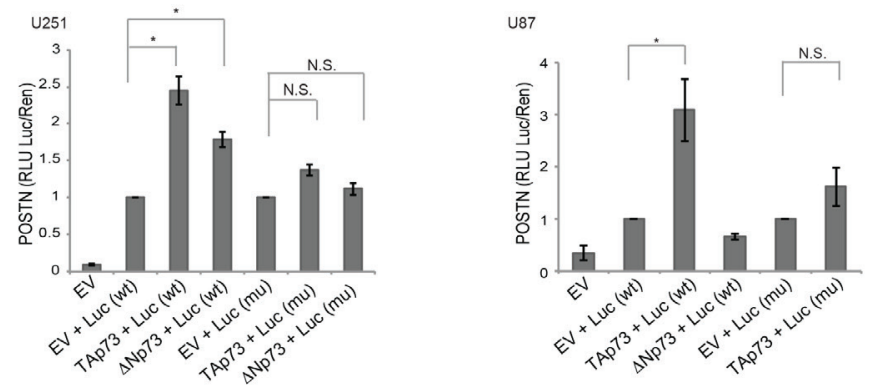

H) 425

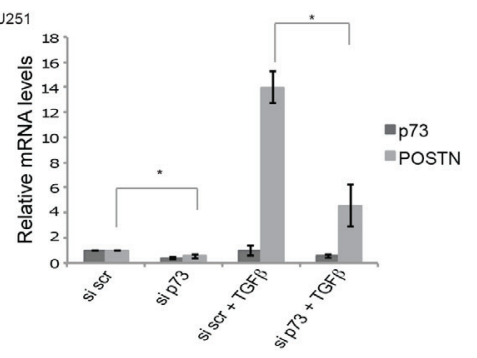

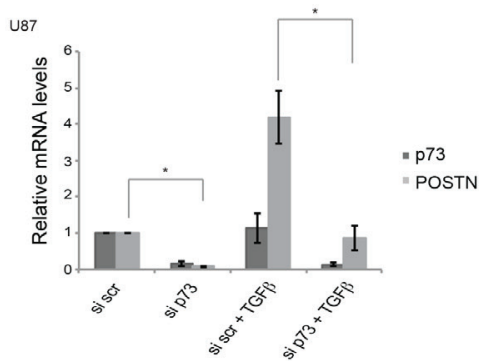

Figure 4: POSTN is a direct target of p73. A. High POSTN mRNA expression is strongly correlated with reduced survival of glioblastoma patients. Data is from the REMBRANT database/NIH (https://caintegrator.nci.nih.gov/rembrandt/). $p$-value corresponds to comparison between all three conditions with each other. B. Expression of POSTN mRNA $72 \mathrm{~h}$ after transfection with $\mathrm{p} 73$ or scr siRNA was determined using RT- qPCR in U251 (left panel) and U87 (right panel) cells. C. U251 protein extracts of cells transfected with siRNA for p73 or a scrambled control and analysed by immunoblotting using p73, POSTN and $\beta$-tubulin antibodies. Asterisk indicates an unspecific band of the p73 antibody. D. Expression of POSTN mRNA $24 \mathrm{~h}$ after transfection with plasmids encoding TAp $73 \alpha, \Delta \mathrm{Np} 73 \alpha$ or an empty vector control was determined using RT-qPCR in U251 (left panel) and U87 (right panel) cells. E. Analysis of the POSTN promoter revealed one potential binding site for transcription factors of the $\mathrm{p} 53$ family $600 \mathrm{bp}$ upstream of the transcriptional start site. F. ChIP assay demonstrating binding of TAp73 $\alpha$ to the POSTN promoter in U251 cells. G. U251 (left panel) or U87 (right panel) cells were transfected with p 73 constructs (TAp73 $\alpha$ or $\triangle \mathrm{Np} 73 \alpha$ ) plus POSTN-Luc wt or mutant and control Renilla-Luc. Post transfection (24 h), cells were harvested and dual luciferase reporter assays performed. Results were normalised by expressing firefly/renilla luciferase activity in relative light units (RLU) as the mean +/- S.D.H. H. U251 (left panel) or U87 (right panel) cells were transfected with siRNA (p73 or scrambled control), $48 \mathrm{~h}$ post transfection cells were treated with $5 \mathrm{ng} / \mathrm{ml} \mathrm{TGF} \beta$ for another $24 \mathrm{~h}$. Cells were harvested and mRNA expression of $\mathrm{p} 73$ and POSTN was analysed using RT-qPCR. ${ }^{*} p<0.05,{ }^{* *} p<0.001$. Error bars represent SEM. 


\section{POSTN is a direct target of $p 73$}

To gain insight into the mechanism of how p73 regulates cell migration, we decided to study the regulation of one of the genes identified in the microarray in more detail. We chose POSTN (Periostin), as it has previously been implicated in glioblastoma malignancy and to be important for EMT and cancer metastasis [96-98]. The matricellular protein POSTN was initially identified as a cell adhesion protein in a mouse osteoblastic cell line [99, 100]. More recently a role of POSTN in carcinogenesis and metastasis has been discovered [101, 102]. Numerous studies showed an up-regulation of both POSTN protein and mRNA levels in a plethora of different tumours, including glioblastoma, neuroblastoma, breast, colon and pancreatic cancer $[96,101]$. We used the Rembrandt

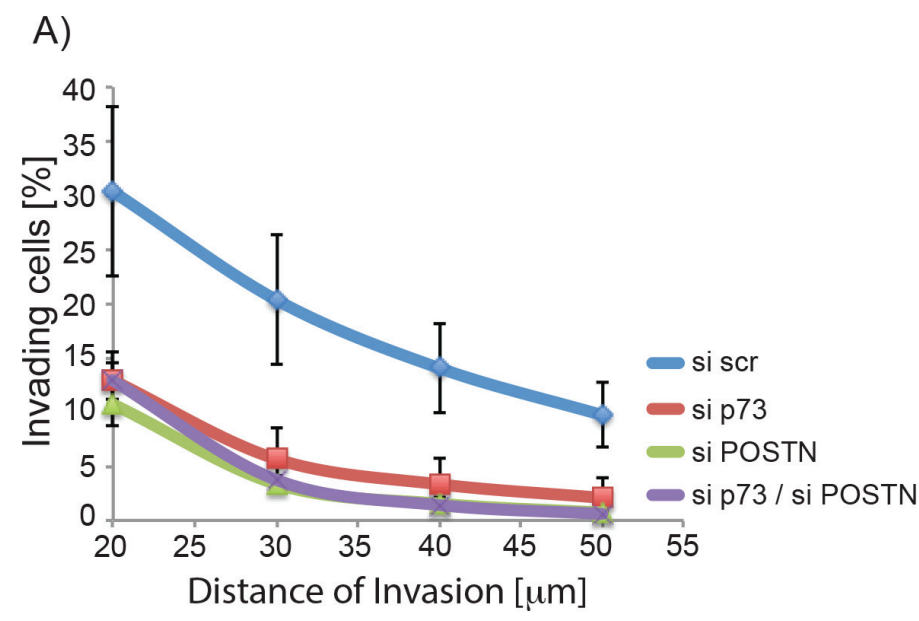

B)

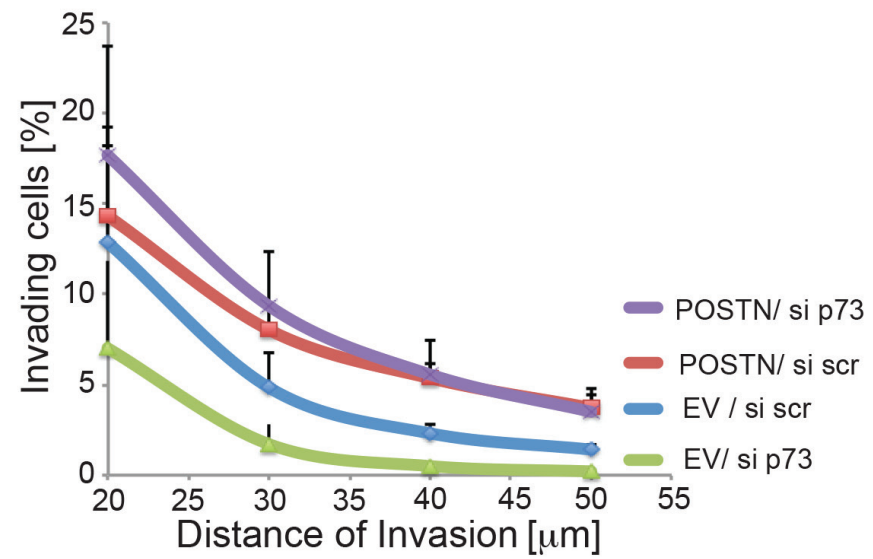

database to examine the effect of POSTN mRNA upregulation on patient survival and found that POSTN overexpression correlates strongly with poor prognosis in glioblastoma patients (Figure 4A). To study the regulation of POSTN by p73, we initially used knock down experiments in U251 and U87 glioblastoma cell lines, where both full p73 and specifically the transcriptionally active TAp73 isoform expression were abolished. As shown in Figure 4B, both the isoform specific and total knock down resulted in a striking decrease of POSTN mRNA levels in both cell lines. Furthermore, knock down of p73 also led to a marked decrease of POSTN protein levels (Figure 4C). Correspondingly, when TAp73 is overexpressed there is a small, but significant increase in POSTN mRNA levels, while $\Delta \mathrm{Np} 73$ has no effect on its expression (Figure 4D).

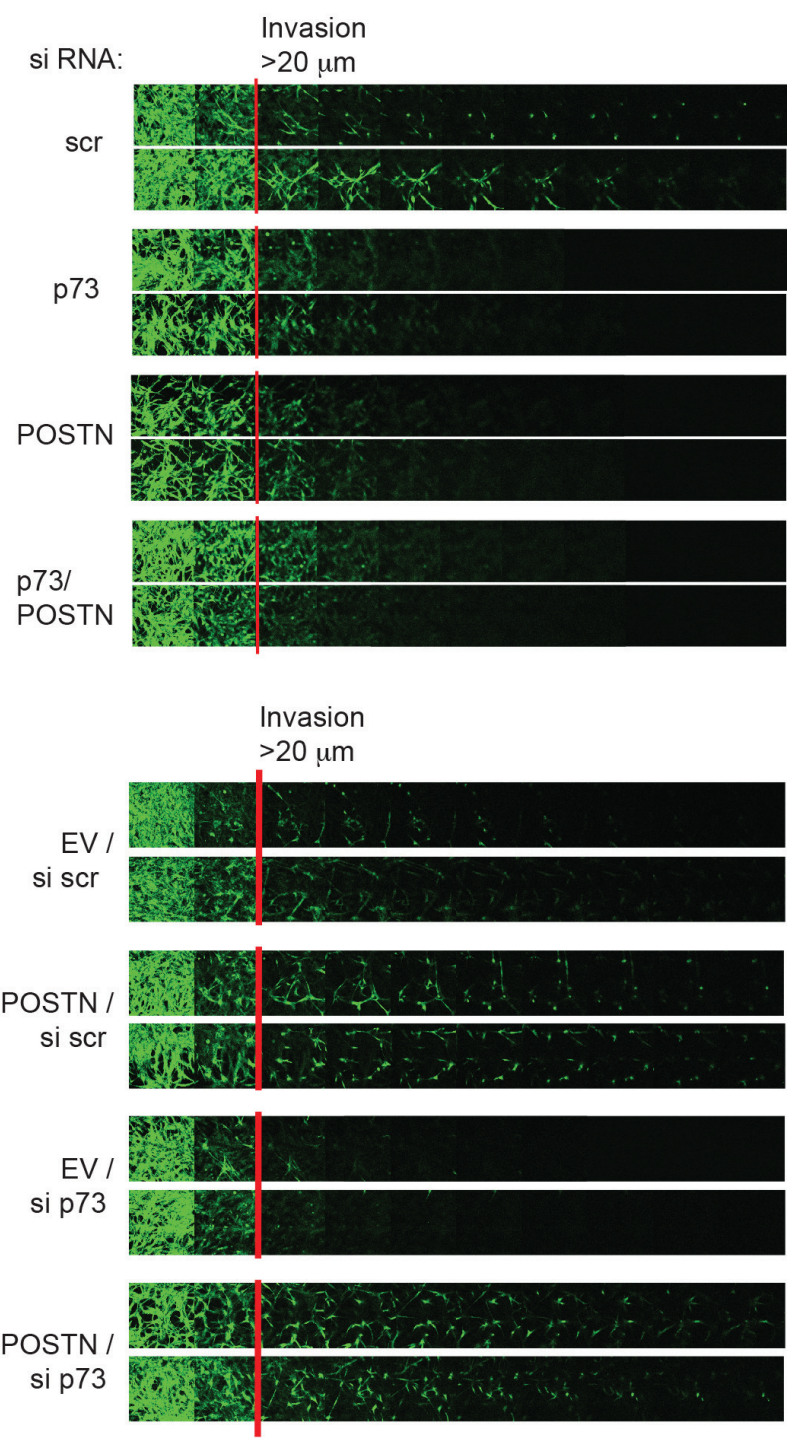

Figure 5: POSTN overexpression rescues invasion ability of glioblastoma cells with p73 knock down. A. Invasion into matrigel of U251 cells that were transfected with siRNA targeting p73, POSTN, both or a nontargeting control is shown. B. As in A, but cells were transfected with siRNA (scr or p73) and plasmids encoding POSTN or empty vector as indicated. 
To investigate whether POSTN is a direct transcriptional target of TAp73 we performed a promoter analysis of the POSTN gene and found one potential p73 binding site $\sim 600$ bp upstream of the POSTN transcriptional start site (Figure 4E). We employed chromatin immunoprecipitation (ChIP) assays to investigate binding of TAp73 to this potential binding site using overexpression of TAp73 $\alpha$-HA in U251 cells followed by DNA-protein crosslinking and isolation of TAp $73 \alpha$ using an HA antibody. The results showed that TAp73 bound to the POSTN promoter, as well as to the MDM2 promoter used as a positive control (Figure 4F). To confirm that TAp73 activates the POSTN promoter, reporter assays were carried out using the POSTN promoter, either in its wild type form or with a threenucleotide deletion in the previously identified p73 binding site (Figure 4G). The results showed that TAp73, and in U251 cells also $\Delta \mathrm{Np} 73$, transcriptionally activates reporter activity in both $\mathrm{U} 251$ and $\mathrm{U} 87$ cells, and that this is abrogated when the p73 binding site is mutated. Taken together the data from the ChIP and reporter assays demonstrated direct binding of TAp73 to the POSTN promoter leading to POSTN transcription.

Expression of POSTN is induced via the TGF $\beta$ pathway, and we next asked whether p73 is also required to activate POSTN expression when induced by TGF $\beta$. To
A)

Ctrl
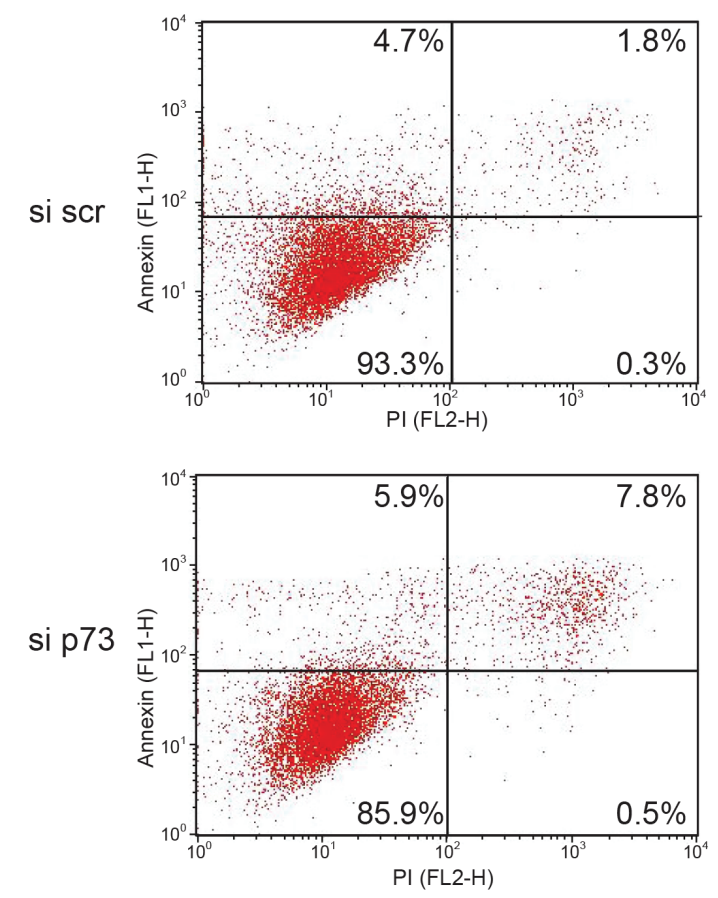

B)

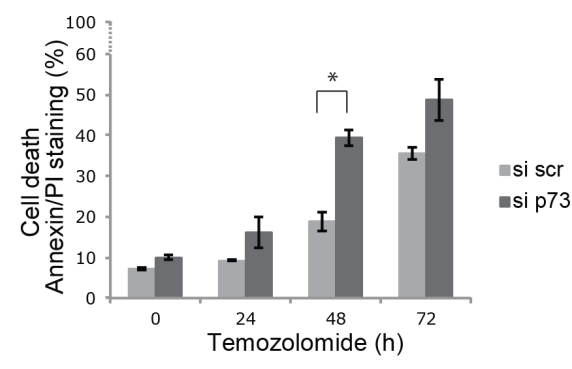

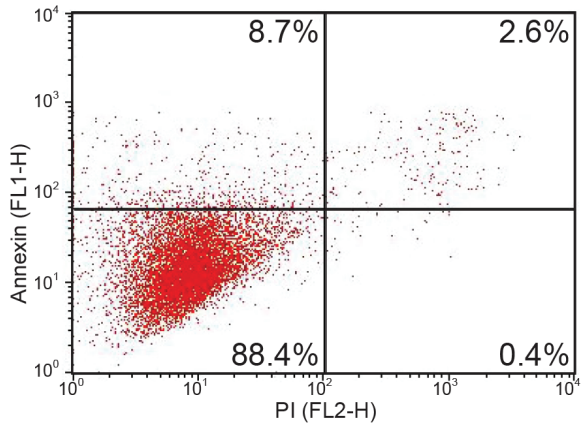

Temozolomide

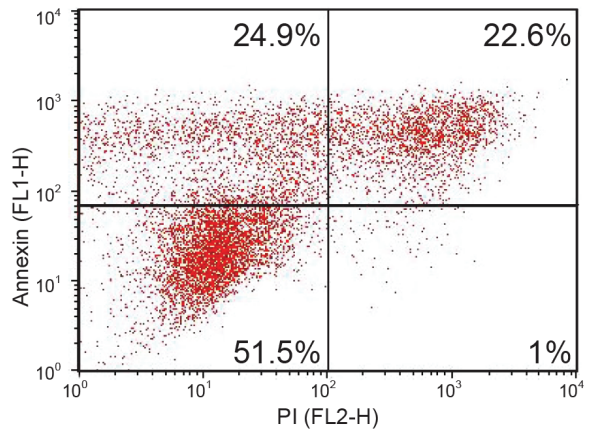

C)
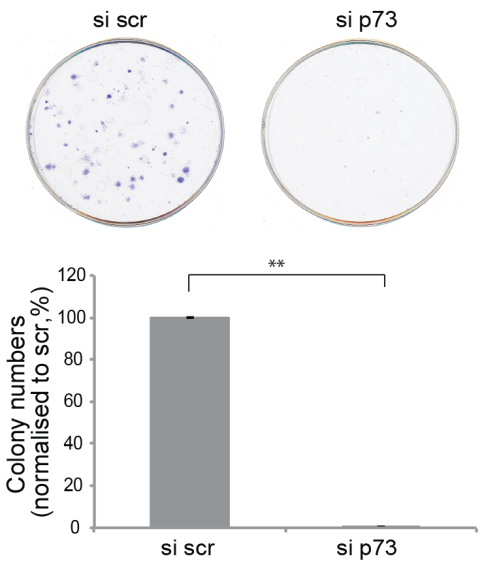

Figure 6: Glioblastoma are more chemo-sensitive after p73 knock down. A. U251 cells were treated with $50 \mu \mathrm{M}$ Temozolomide for $48 \mathrm{~h}$. Early and late apoptosis was detected using Annexin V/PI-double staining followed by flow cytometry analysis. B. As in A, but with additional time points of Temozolomide treatment of 24 and $72 \mathrm{~h}$, total apoptosis was quantified and is shown. C. Colony formation assay after p73 knock down. ${ }^{*} p=0.05, * * p<0.0001$. Error bars represent SEM. 
test this, cells were transfected with either siRNA targeting total $\mathrm{p} 73$ or a scrambled control, treated with TGF $\beta$ and mRNA levels of POSTN and p73 were measured using RT-qPCR. As expected, TGF $\beta$ treatment led to a strong increase in POSTN mRNA and knock down of p73 reduced this by around 3 fold, further demonstrating that p73 plays a role in POSTN activation (Figure $4 \mathrm{H}$ ).

The fact that p73 knock down reduced the activation of POSTN in response to TGF $\beta$ treatment suggests that $\mathrm{p} 73$ acts downstream of TGF $\beta$ in this pathway. It remains to be investigated how/if $\mathrm{p} 73$ is directly activated by TGF $\beta$ leading to an increase of POSTN expression. p73 mRNA levels do not change after TGF $\beta$ treatment, suggesting that p73 activity could be modified by post translational modifications.

Since POSTN is known to promote invasion of glioblastoma cells we speculated that the reduction of POSTN after p73 knock down is, at least in part, responsible for the loss of invasive ability of the cells.
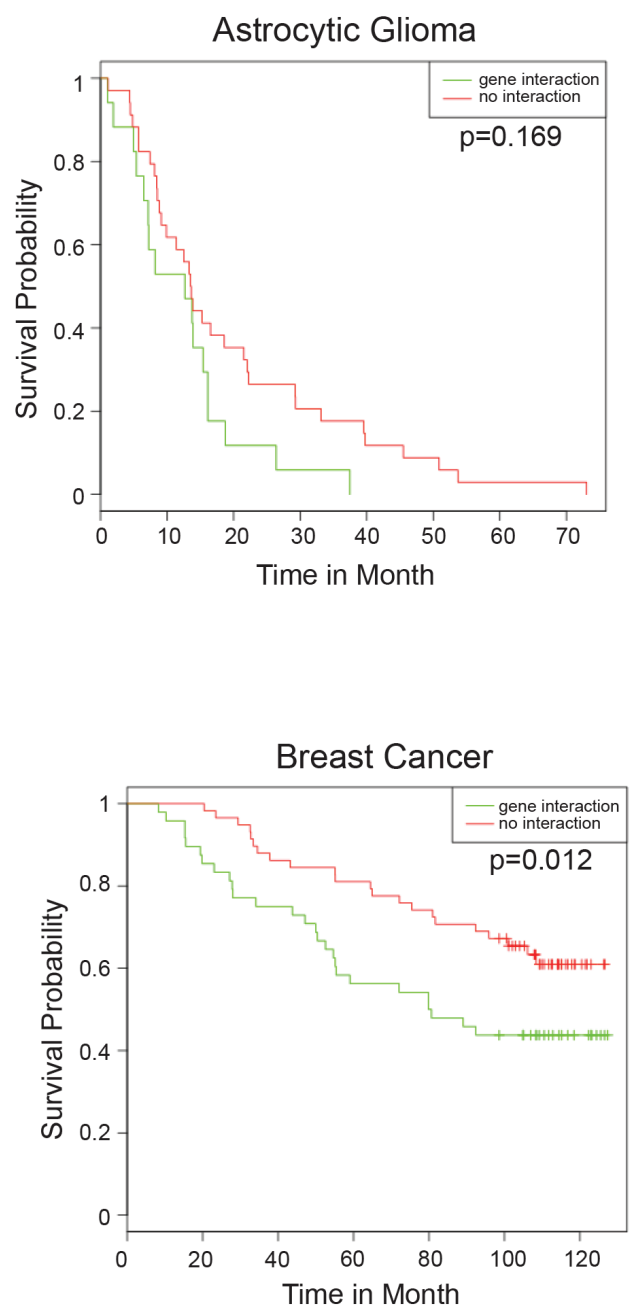

To test this we performed an invasion assay with cells transfected with siRNA for total p73, POSTN or both. As expected loss of either p73 or POSTN decreased invasion of glioblastoma cells; however, a double knock down of both did not lead to further reduction in invasion, suggesting that indeed both proteins are acting in the same pathway with $\mathrm{p} 73$ regulating POSTN expression (Figures 5A, S5A). To further support this hypothesis, we overexpressed POSTN in cells (Figure S5B) transfected with either siRNA for total p73 or control cells to see if POSTN expression can rescue the invasive phenotype of these cells. As shown in Figure 5B, overexpression of POSTN led to a strong increase in invasion that is not reduced after p73 knock down. Moreover, the reduced invasion produced by p73 knock down is rescued by overexpression of POSTN.

Taken together this data demonstrates that p73 regulates POSTN levels and thereby invasion of glioblastoma cells.
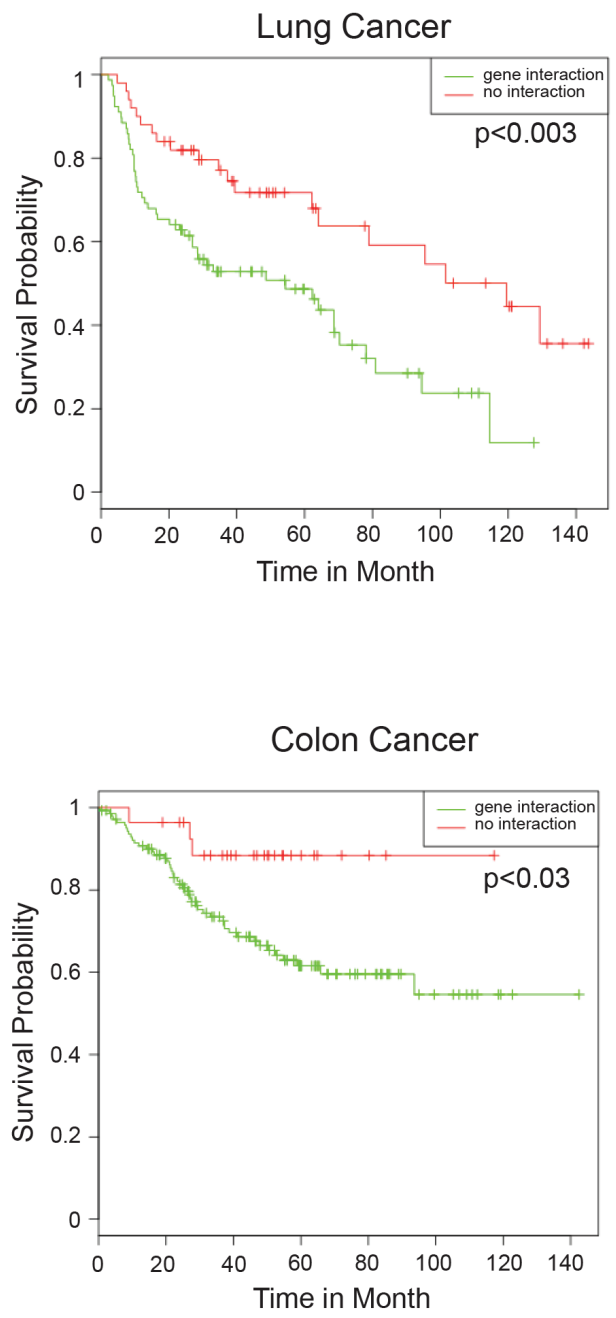

Figure 7: Correlation of p73 and POSTN expression predicts bad patient prognosis. Positive total p73/POSTN correlation represents a negative prognostic factor for patient survival in astrocytic gliomas (dataset: GSE18166, $N=51$ ), lung $(\mathrm{GSE} 4573, N=128)$, breast cancer $(\mathrm{GSE} 19783, N=106)$ and colon cancer $(\mathrm{GSE} 17538, N=566)$. Panels represent patient survival estimation of p73/POSTNpositive correlation groups compared with negative or absent correlation groups. 


\section{Loss of p73 leads to a decreased chemo-resistance}

As an undifferentiated phenotype of glioblastoma cells is usually associated with increased invasiveness and chemoresistance, we investigated the effect of total p73 knock down on glioblastoma cell sensitivity to Temozolomide. We measured apoptosis in cells after drug treatment using Annexin V/PI staining. p73 knock down led to a modest, but significant, increase of apoptosis after treatment with the Temozolomide (Figure 6A, 6B). Additionally, we examined the effect of POSTN overexpression on apoptosis after Temozolomide treatment with and without p73 knock down. However, no change in cell death after POSTN overexpression was observed, irrespectively of p73 knock down (Figure S6). This suggests that the effect on chemo-resistance after p 73 knock down is mediated by a different axis compared to the effect on cell invasion and is POSTN independent.

As we observed cell differentiation after p 73 knock down and this is often associated with a decrease in proliferation we, furthermore, probed the effect of p73 on cell proliferation using a colony formation assay. The results showed a dramatic decrease of cell proliferation after total p73 knock down (Figure 6C).

\section{Correlation between p73 and POSTN levels predicts bad prognosis for patient survival}

If up-regulation of POSTN by p 73 leads to increased invasion, we would expect that the tumours in which this regulation is active and thus POSTN and p73 levels correlate, are more aggressive and have a worse prognosis than tumours where this axis is not functional. To assess this bioinformatically, glioblastoma datasets from patients were divided into two groups; those where p73 and POSTN mRNA correlate and those where there is no correlation. We then compared the survival probability of the two groups (Figure 7). While the survival of the group where POSTN and p73 levels correlate is decreased, the difference between this group and that in which there is no interaction does not reach significance, possibly because the sample size is too small. We therefore decided to probe other cancers, specifically lung, breast cancer and colon cancer, where larger datasets are available. And importantly, POSTN was implicated to be a negative prognostic marker in breast [103, 104], lung cancer [105, 106] and colon cancer [107, 108]. All three datasets show a dramatic, and statistically significant, reduction in survival of patients where levels of p73 and POSTN correlate (Figure 7). Taken together we have shown that p73 ablation leads to morphological changes associated with a differentiated phenotype in glioblastoma cells, that leads to a decrease in their invasion ability through inactivation of the p73/POSTN axis.

\section{DISCUSSION}

In the current study we demonstrate that p73 promotes invasion and migration in glioblastoma cells through directly activating expression of POSTN. Previous studies have proposed a role for p73 in cell migration and invasion. Sablina et al (2003) showed that TAp73 leads to increased colon cancer cell migration [109], while Zhang et al (2012) observed a reduction of cell migration in non-cancerous breast cells (MCF10a) after TAp73 overexpression [110], suggesting that the effect is cell type and condition dependent. The $\Delta \mathrm{Np} 73$ isoform has also been implicated with increased invasion and metastasis in a study by Steder et al, [111], that showed that $\Delta \mathrm{Np} 73$ can initiate metastasis by inhibiting IGF1R-AKT/STAT3 signalling.

Here we show that, strikingly, loss of p73 leads to a differentiated phenotype that is less invasive and more susceptible to chemotherapeutic treatment in glioblastoma cells. Using a gene microarray, we identified POSTN as a direct transcriptional target of $\mathrm{p} 73$ that is strongly down regulated in glioblastoma cells upon p73 loss. A previous study has shown regulation of POSTN mRNA by p73 in a thyroid cancer cell line [109]. Here, however, we show for the first time that p73 directly binds to the POSTN promoter to activate its transcription and that $\mathrm{p} 73$ directly regulates POSTN protein levels. The study of POSTN regulation by $\mathrm{p} 73$ in thyroid cancer detected a strong upregulation of POSTN expression in a reporter assay in response to $\triangle \mathrm{Np} 73$ overexpression, while we did not observe an upregulation of POSTN mRNA in response to $\triangle \mathrm{Np} 73$ and only a mild effect in a reporter assay. This could be due to cell type specific non-transcriptional activation of POSTN by $\triangle \mathrm{Np} 73$, as this isoforms does not have intrinsic transcriptional activity.

Several studies have demonstrated that POSTN is up regulated in a variety of tumours, including glioblastoma $[96,101]$, and acts as a metastasis-promoting factor [102]. Likewise, POSTN has been shown to promote epithelial to mesenchymal transition leading to increased cell invasion and proliferation [98, 112, 113]. In addition to being overexpressed by tumour cells, POSTN is also expressed in the stroma of normal stem cell niches and aids the metastatic success of circulating cancer cells [102]. Taken together, these data suggests that POSTN plays an important role in tumour formation and metastasis, being either expressed by the tumour cells or the surrounding stroma.

Here we have demonstrated that TAp73 directly activates POSTN expression leading to an invasive phenotype in glioblastoma cells. Moreover, total p73 knock down renders glioblastoma cells more sensitive to Temozolomide treatment and bioinformatic analysis revealed that correlation of $\mathrm{p} 73$ and POSTN expression predicts poor patient survival. This suggests that the $\mathrm{p} 73 /$ POSTN axis is a negative predictive factor of patient 
survival that might drive carcinogenesis. Further studies, especially in vivo, are necessary to establish whether p73 or its target POSTN could provide a drug target for development of new drugs that reduce glioblastoma invasion.

\section{MATERIALS AND METHODS}

\section{Cell culture, transfections and reporter assay}

Glioblastoma cell lines U251 and U87 were maintained in DMEM (Life Technologies) and EMEM (ATCC) respectively; all media were supplemented with $10 \%$ FBS (v/v) (Labtech) and $1 \%$ (v/v) penicillin/ streptomycin (Invitrogen), and grown with $5 \% \mathrm{CO}_{2}$ at $37^{\circ} \mathrm{C}$. To maintain cells, U251 and U87 cells were grown to 90 and $70 \%$ confluence respectively and then split 1:8 using trypsin:EDTA (Gibco).

Transfection of cells with siRNA was carried out using Hyperfect (Qiagen) at 60\% (U251) and 50\% (U87) confluence following the supplier's instructions using $30 \mathrm{nM}$ siRNA, siRNA Silencer Select was from Ambion (IDs: TAp73: 115665, total p73: 2671, POSTN: s20889). DNA transfections were carried out using Effectene (Qiagen) at 80\% confluence and Lipofectamine 2000 (Life Technologies) at 70\% confluence for U251 and U87 respectively.

\section{Reporter assay}

Reporter activity was tested using the Dual Luciferase Reporter System from Promega. Briefly, cells were seeded in 24 well plates and transfected with Renilla (50 ng/well), POSTN reporter construct wt or mutant (120 ng/well) and $100 \mathrm{ng}$ of the indicated p73 isoforms. After $24 \mathrm{~h}$, cells were washed and lysed on the plate using the Promega lysis buffer. Firefly luciferase and Renilla activities were measured as indicated by Promega. Results shown are firefly luciferase expression normalised by Renilla and are expressed as relative light units (RLU). Results are shown as the median of 3 independent experiments, all carried out in duplicate and measured twice.

\section{Plasmids, antibodies and western blot}

Antibodies were anti-p73 (Melino lab [114]), antiSNAIL (Cell Signalling L70G2, mAb), anti-E-Cadherin (Cell Signalling 4A2, mAb), anti-POSTN, anti-GFAP (DAKO, pAb). Anti-GAPDH (SIGMA, G8795, mAb) and anti- $\beta$-tubulin (Santa Cruz H-235, pAb). Secondary antibodies were HRP conjugated goat-anti-rabbit and goat-anti-mouse (Bio Rad), and Alexa Flour 488 donkey anti-rabbit (Molecular Probes). Cells were lysed in Triton $\mathrm{X}-100$ lysis buffer (50 mM HEPES (pH 8), $0.4 \%$ Triton $\mathrm{X}-100,150 \mathrm{mM} \mathrm{NaCl}, 10 \mathrm{mM} \mathrm{NaF}, 2 \mathrm{mM}$ DTT, 0.1 mM EDTA, 1x protease inhibitor mix (Roche)). Western Blotting was performed as described previously [115].

The POSTN gene was subcloned into the pcDNA 3.1 (-) vector (Life Technologies) after PCR amplification of the gene from U251 cell cDNA using the following primers including the restriction sites for NheI and Hind III,

Fw:

5'GCTACGGCTAGCATGATTCCCTTTTTACCCATG'3, Rv: 5 ,

GCTACGAAGCTTTCACTGAGAACGACCTTCCC'3.

For the Luciferase reporter assay a reporter construct with $1000 \mathrm{bp}$ of the POSTN promoter upstream of the transcription start site were cloned into the pGL3-Basic Vector (Promega). The region was amplified using PCR from genomic U251 cell DNA using the following primers including restriction sites for SacI and BgIII:

Fw:

5'CATGGAGCTCTGGCTAGGGATTGCATAGTGT'3, Rv:

5'CATGAGATCTAGAACTGGCAGTGGGCTTTG'3.

A deletion mutant of the plasmid was created using the Quick Change II XL Site directed mutagenesis Kit (Agilent Technologies) and the following primers

Fw: 5'GATGTGCTGCATAGATTCAACATCAC3', Rv: 5'GTGATGTTGAATCTATGCAGCACATC3'.

Restriction enzymes and T4 DNA Ligase were purchased from NEB and restriction digest, ligation and transformation into competent cells (DH5 $\alpha$, Life Technologies) were carried out following the supplier's instructions.

\section{Inverted invasion assay}

The inverted invasion assay was carried out as described previously [116]. In brief, geltrex (Gibco, A1413302) was mixed 1:1 with PBS and supplemented with $25 \mu \mathrm{g} / \mathrm{ml}$ fibronectin (FN, Sigma), $60 \mu \mathrm{l}$ of the mix was added to each transwell dish $(8 \mu \mathrm{m}$ polycarbonate membrane, Costar) and allowed to set at $37^{\circ} \mathrm{C}$ for $45 \mathrm{~min}$. Next 30,000 cells were added to the top of the membrane and transwells were incubated upside down for $4 \mathrm{~h}$ to allow cells to settle on the membrane. The wells were then washed twice by dipping into serum free media and placed in $1 \mathrm{ml}$ serum free media in a 24 well plate. On top of the geltrex layer $100 \mu \mathrm{l}$ serum-rich media was added supplemented with $10 \mathrm{ng} / \mathrm{ml}$ EGF and $10 \mathrm{ng} / \mathrm{ml} \mathrm{HGF}$. Cells were incubated for $72 \mathrm{~h}$ and stained using $4 \mu \mathrm{M}$ Calcein-AM (Santa Cruz Biotechnology) in media for $1 \mathrm{~h}$. Invading cells were quantified using confocal microscopy by taking pictures every $10 \mu \mathrm{m}$ throughout the geltrex matrix. 


\section{Migration assay}

Migration assays were carried out using the $\mathrm{xCELLigence} \mathrm{system} \mathrm{(ACEA} \mathrm{Bioscience)} \mathrm{following} \mathrm{the}$ supplier's instructions. Briefly, cells were harvested and washed in serum free media, and 20,000 cells were added to the upper chamber of the CIM plate, with the lower chamber filled with serum rich media. Cells were allowed to migrate for up to $60 \mathrm{~h}$ and the numbers of migrated cells read every $15 \mathrm{~min}$.

\section{Immunofluorescence}

Cells were transfected and incubated as indicated in the figure legends and then fixed using $3 \%$ paraformaldehyde in PBS. After blocking and permeabilisation for $1 \mathrm{~h}(0.4 \%$ Triton X-100, $1 \%$ BSA in PBS), the 96 well plates were incubated with $\alpha$-GFAP antibody (1:500) in $1 \% \mathrm{BSA}$ in PBS overnight at $4^{\circ} \mathrm{C}$. After 3 washes (10 min each) in PBST the slides were incubated in secondary antibody $(1: 1000)$ for $30 \mathrm{~min}$ at $37^{\circ} \mathrm{C}$, washed again twice with PBST and then incubated for 10 min in PBS containing Hoechst Staining (1:10000). Cells were visualised using the Cellomics (Thermo Fisher).

\section{Colony formation assay}

For the colony formation assay U251 cells were transfected with si scr or si p73. $24 \mathrm{~h}$ post transfection 500 cells were seeded per well of a 6 well plate in duplicate. After 2 weeks cells colonies were stained using crystal violet. The experiment was carried in 3 independent biological replicates.

\section{Annexin V/ PI}

U251 cells were seeded in 6 well plates and transfected with $30 \mathrm{nM}$ siRNA targeting p73 or a scrambled control, $24 \mathrm{~h}$ post transfection cells were treated with $50 \mu \mathrm{M}$ Temozolomide for the times indicated. Apoptosis was measured using the Annexin V-FITC Apoptosis Detection Kit (eBioscience) following the supplier's instructions. Staining was analysed using the FACS Calibur (Becton Dickinson) with CellQuestPro Software, per sample 10,000 cells were analysed.

\section{RT-qPCR and PCR}

RNA was isolated from cells using the TRIZOL reagent (Life Technologies). For RT-qPCR first $3 \mu \mathrm{g}$ of isolated RNA was digested using DNase (SIGMA) to eliminate any DNA contamination and then cDNA was generated using the Revert Aid cDNA synthesis kit (Life Technologies). Actual qPCR Primer for RT-qPCR were:
L32
(internal
control)
Fw:

TTCCTGGTCCACAACGTCAAG

Rv: TGTGAGCGATCTCGGCAC,

total p73: Fw: GCCTGGAGCTGATGGAGTT,

Rv:ACGGGGGCTGTAGGTGAC, POSTN: Fw:CTCATAGTCGTATCAGGGGTCG

Rv: ACACAGTCGTTTTCTGTCCAC.

RT-PCR and PCR were carried out as described previously [117].

\section{Microarray analysis}

RNA was extracted from U251 cells that had been transfected with siRNA (scr or p73) $72 \mathrm{~h}$ prior to RNA isolation using TRIZOL (Invitrogen). Next, RNA was reverse transcribed, converted to cRNA, amplified, and labeled with a cyanine-3 dye using a Low Input Quick Amp labeling kit (Agilent). Then cRNAs were hybridized to human gene expression microarrays (Agilent, catalog number G4851B) containing 50,599 different probes. Slides were washed with the Agilent wash buffer reagents and scanned using the G2505C Agilent Microarray Scanner (scan control version A.8.4.1). Using the Agilent Feature Extraction software (version 10.7.3.1) data was extracted and analyzed using Agilent GeneSpring GX software (version 12.1). To analyze significant differential expression, an unpaired Student's t test with Benjamini-Hochberg multiple testing correction was applied. Hits with a $p$-value $\leq 0.05$ and a fold change $>2$ were considered to be both statistically and biologically significant.

\section{Analysis of promoter region}

To analyse potential p73 binding sites within the POSTN promoter an analysis was carried out using Math-Inspector Professional software and the TRANSFAC database on a region of $3000 \mathrm{~kb}$ upstream of the transcription-start site and within the first intron of human POSTN. The analysis highlighted a $25 \mathrm{bp}$ region containing a p53-like RE site roughly 600 bp upstream of the transcription start site [118].

\section{Chromatin immunoprecipitation (ChIP) assay}

ChIP assays were carried out using the MAGnify ${ }^{\mathrm{TM}}$ Chromatin Immunoprecipitation System (Life Technologies) following the manufacturer's instructions. Briefly, U251 cells were transfected with HA-TAp $73 \alpha$ DNA, harvested $24 \mathrm{~h}$ post transfection and fixed using formaldehyde. After sonication an immunoprecipitation for TAp73 was performed using an HA antibody 
(Covance) or an IgG control, cross-linking was reversed and DNA eluted using the components of the kit. An PCR was performed on the input and diluted DNA using the following primers:

POSTN Fw:5'CAATATTGGCTGCTTTTCACCA'3, Rv: 5'AAGGTTTGAAATGAAGCAGAAAGG'3, MDM2

Fw: 5'GGTTGACTCAGCTTTTCCTCTTG'3, Rv: 5'GGAAAATGCATGGTTTAAATAGCC'3.

\section{Bioinformatics analyses}

Gene expression data sets GSE18166, GSE17538, GSE4573 and GSE19783 were downloaded from the GEO omnibus repository. The gene expression rank that reflects relative mRNA expression levels is more consistent as it does not require normalization and thus no normalization bias is introduced [94, 119-121]. Gene expression values were transformed into rank expression values on a scale from 100 to 0 , where a rank value of 55 shows that $55 \%$ of probes in the sample have a lower expression value for a given gene. Pearson coefficient was used as a measure of correlation between expression profiles.

To divide the data sets into two cohorts, one where the positive correlation between expression profiles of total p73 and POSTN is maximized (in cohort 1) and one where it is minimized (cohort 2), first all samples are placed in cohort 1 and no samples in cohort 2. Next correlation between p73 and POSTN expression profiles in cohort 1 was computed, as well as the changes in correlation if one sample from the cohort was removed. The sample with maximal effect on correlation (maximal increase in positive correlation) is then moved from cohort 1 to cohort 2. This procedure is repeated until there is no sample left in cohort 1 which increases the positive correlation between p73 and POSTN, if it was removed. Next the statistical difference in survival of the two cohorts was calculated and graphs were blotted using $\mathrm{R}$ (statistical package).

\section{Abbreviations}

POSTN, periostin; GBM, glioblastoma multiforme; TAp73, transactivation domain-containing p73 isoform; $\Delta \mathrm{Np} 73$, amino-truncated p73 isoform; GFAP, glial fibrillary acidic protein; EMT, epithelial to mesenchymal transition; ChIP, chromatin immunoprecipitation.

\section{ACKNOWLEDGMENTS}

We thank K. Dudek for assistance in gene microarray analysis, L. Pinon for assistance with imaging using the Cellomics, P. Muller for help setting up the inverted invasion assay and M. Agostini, I. Amelio and B. Rotblat for scientific discussion.

\section{GRANT SUPPORT}

This work has been supported by the Medical Research Council, UK; grants from Associazione Italiana per la Ricerca contro il Cancro (AIRC; 2011-IG11955; 5xmille MCO \#9979) and Fondazione Roma (NCD), Min. Salute to Istituto Dermopatico dell'Immacolata/Istituto di Ricovero e Cura a Carattere Scientifico (IDI-IRCCS RF08 c. $15, \mathrm{RF} 07$ c.57) to GM.

\section{CONFLICTS OF INTEREST}

There is no conflict of interest.

\section{REFERENCES}

1. Jackson M, Hassiotou F and Nowak A. Glioblastoma stemlike cells: at the root of tumor recurrence and a therapeutic target. Carcinogenesis. 2015; 36:177-185.

2. Chen J, McKay RM and Parada LF. Malignant glioma: lessons from genomics, mouse models, and stem cells. Cell. 2012; 149:36-47.

3. Auffinger B, Tobias AL, Han Y, Lee G, Guo D, Dey M, Lesniak MS and Ahmed AU. Conversion of differentiated cancer cells into cancer stem-like cells in a glioblastoma model after primary chemotherapy. Cell death and differentiation. 2014; 21:1119-1131.

4. Dickinson A, Yeung KY, Donoghue J, Baker MJ, Kelly RD, McKenzie $M$ and Johns TG. The regulation of mitochondrial DNA copy number in glioblastoma cells. Cell death and differentiation. 2013; 20:1644-1653.

5. Lugli N, Kamileri I and Halazonetis TD. PARP inhibitors and IR join forces to strike glioblastoma-initiating cells. Cell death and differentiation. 2014; 21:192-193.

6. Zhang Y, Kim J, Mueller AC, Dey B, Yang Y, Lee DH, Hachmann J, Finderle S, Park DM, Christensen J, Schiff D, Purow B, Dutta A and Abounader R. Multiple receptor tyrosine kinases converge on microRNA-134 to control KRAS, STAT5B, and glioblastoma. Cell death and differentiation. 2014; 21:720-734.

7. Bageritz J, Puccio L, Piro RM, Hovestadt V, Phillips E, Pankert T, Lohr J, Herold-Mende C, Lichter P and Goidts V. Stem cell characteristics in glioblastoma are maintained by the ecto-nucleotidase E-NPP1. Cell death and differentiation. 2014; 21:929-940.

8. Liu JK, Lubelski D, Schonberg DL, Wu Q, Hale JS, Flavahan WA, Mulkearns-Hubert EE, Man J, Hjelmeland $\mathrm{AB}, \mathrm{Yu}$ J, Lathia JD and Rich JN. Phage display discovery of novel molecular targets in glioblastoma-initiating cells. Cell death and differentiation. 2014; 21:1325-1339.

9. Tchoghandjian A, Jennewein C, Eckhardt I, Momma S, Figarella-Branger D and Fulda S. Smac mimetic promotes glioblastoma cancer stem-like cell differentiation by activating NF-kappaB. Cell death and differentiation. 2014; 
21:735-747.

10. Ciceroni C, Bonelli M, Mastrantoni E, Niccolini C, Laurenza M, Larocca LM, Pallini R, Traficante A, Spinsanti P, Ricci-Vitiani L, Arcella A, De Maria R, Nicoletti F, Battaglia G and Melchiorri D. Type-3 metabotropic glutamate receptors regulate chemoresistance in glioma stem cells, and their levels are inversely related to survival in patients with malignant gliomas. Cell death and differentiation. 2013; 20:396-407.

11. Leszczyniecka M, Roberts T, Dent P, Grant S and Fisher PB. Differentiation therapy of human cancer: basic science and clinical applications. Pharmacology \& therapeutics. 2001; 90:105-156.

12. Li Y, Yin W, Wang $X, Z$ hu W, Huang $Y$ and Yan G. Cholera toxin induces malignant glioma cell differentiation via the PKA/CREB pathway. Proceedings of the National Academy of Sciences of the United States of America. 2007; 104:13438-13443.

13. Venere M, Hamerlik P, Wu Q, Rasmussen RD, Song LA, Vasanji A, Tenley N, Flavahan WA, Hjelmeland AB, Bartek J and Rich JN. Therapeutic targeting of constitutive PARP activation compromises stem cell phenotype and survival of glioblastoma-initiating cells. Cell death and differentiation. 2014; 21:258-269.

14. Cruz FD and Matushansky I. Solid tumor differentiation therapy - is it possible? Oncotarget. 2012; 3:559-567. doi: 10.18632/oncotarget.512.

15. Dotsch V, Bernassola F, Coutandin D, Candi E and Melino G. p63 and p73, the ancestors of p53. Cold Spring Harbor perspectives in biology. 2010; 2:a004887.

16. Dulloo I, Phang BH, Othman R, Tan SY, Vijayaraghavan A, Goh LK, Martin-Lopez M, Marques MM, Li CW, Wang de Y, Marin MC, Xian W, McKeon F and Sabapathy K. Hypoxia-inducible TAp73 supports tumorigenesis by regulating the angiogenic transcriptome. Nature cell biology. 2015; 17:511-523.

17. Zambetti GP. Expanding the reach of the p53 tumor suppressor network. Cell death and differentiation. 2014; 21:505-506.

18. Solomon H, Sharon M and Rotter V. Modulation of alternative splicing contributes to cancer development: focusing on p53 isoforms, p53beta and p53gamma. Cell death and differentiation. 2014; 21:1347-1349.

19. Soussi T and Wiman KG. TP53: an oncogene in disguise. Cell death and differentiation. 2015; 22:1239-1249.

20. Garufi A, Pucci D and D'Orazi V. Degradation of mutant p53H175 protein by $\mathrm{Zn}(\mathrm{II})$ through autophagy. Cell death \& disease. 2014; 5:e1271.

21. Simon HU, Yousefi S, Schmid I and Friis R. ATG5 can regulate p53 expression and activation. Cell death \& disease. 2014; 5:e1339.

22. Ci Y, Shi K, An J, Yang Y, Hui K, Wu P, Shi L and Xu C. ROS inhibit autophagy by downregulating ULK1 mediated by the phosphorylation of p53 in selenite-treated NB4 cells.
Cell death \& disease. 2014; 5:e1542.

23. Evstafieva AG, Garaeva AA, Khutornenko AA, Klepikova AV, Logacheva MD, Penin AA, Novakovsky GE, Kovaleva IE and Chumakov PM. A sustained deficiency of mitochondrial respiratory complex III induces an apoptotic cell death through the p53-mediated inhibition of prosurvival activities of the activating transcription factor 4 . Cell death \& disease. 2014; 5:e1511.

24. Xu J, Wang J, Hu Y, Qian J, Xu B, Chen H, Zou W and Fang JY. Unequal prognostic potentials of p53 gain-offunction mutations in human cancers associate with drugmetabolizing activity. Cell death \& disease. 2014; 5:e1108.

25. Busuttil RA, Zapparoli GV, Haupt S, Fennell C, Wong SQ, Pang JM, Takeno EA, Mitchell C, Di Costanzo N, Fox S, Haupt Y, Dobrovic A and Boussioutas A. Role of p53 in the progression of gastric cancer. Oncotarget. 2014; 5:1201612026. doi: 10.18632/oncotarget.2434.

26. Dashzeveg N, Taira N, Lu ZG, Kimura J and Yoshida K. Palmdelphin, a novel target of p53 with Ser46 phosphorylation, controls cell death in response to DNA damage. Cell death \& disease. 2014; 5:e1221.

27. Manzl C, Fava LL, Krumschnabel G, Peintner L, Tanzer MC, Soratroi C, Bock FJ, Schuler F, Luef B, Geley S and Villunger A. Death of p53-defective cells triggered by forced mitotic entry in the presence of DNA damage is not uniquely dependent on Caspase-2 or the PIDDosome. Cell death \& disease. 2013; 4:e942.

28. Nair BC, Krishnan SR, Sareddy GR, Mann M, Xu B, Natarajan M, Hasty P, Brann D, Tekmal RR and Vadlamudi RK. Proline, glutamic acid and leucine-rich protein-1 is essential for optimal p53-mediated DNA damage response. Cell death and differentiation. 2014; 21:1409-1418.

29. Phesse TJ, Myant KB, Cole AM, Ridgway RA, Pearson H, Muncan V, van den Brink GR, Vousden KH, Sears R, Vassilev LT, Clarke AR and Sansom OJ. Endogenous c-Myc is essential for p53-induced apoptosis in response to DNA damage in vivo. Cell death and differentiation. 2014; 21:956-966.

30. Bisio A, Zamborszky J, Zaccara S, Lion M, Tebaldi T, Sharma V, Raimondi I, Alessandrini F, Ciribilli Y and Inga A. Cooperative interactions between p53 and NFkappaB enhance cell plasticity. Oncotarget. 2014; 5:12111-12125. doi: 10.18632/oncotarget.2545.

31. Kim J, Nakasaki M, Todorova D, Lake B, Yuan CY, Jamora $\mathrm{C}$ and $\mathrm{Xu}$ Y. p53 Induces skin aging by depleting Blimp1+ sebaceous gland cells. Cell death \& disease. 2014; 5:e1141.

32. Li L, Ng DS, Mah WC, Almeida FF, Rahmat SA, Rao VK, Leow SC, Laudisi F, Peh MT, Goh AM, Lim JS, Wright GD and Mortellaro A. A unique role for p53 in the regulation of M2 macrophage polarization. Cell death and differentiation. 2015; 22:1081-1093.

33. Liu J, Zhang C, Wang XL, Ly P, Belyi V, Xu-Monette $\mathrm{ZY}$, Young KH, Hu W and Feng Z. E3 ubiquitin ligase TRIM32 negatively regulates tumor suppressor p53 to 
promote tumorigenesis. Cell death and differentiation. 2014; 21:1792-1804.

34. Peuget S, Bonacci T, Soubeyran P, Iovanna J and Dusetti NJ. Oxidative stress-induced p53 activity is enhanced by a redox-sensitive TP53INP1 SUMOylation. Cell death and differentiation. 2014; 21:1107-1118.

35. Sane S, Abdullah A, Boudreau DA, Autenried RK, Gupta BK, Wang X, Wang H, Schlenker EH, Zhang D, Telleria C, Huang L, Chauhan SC and Rezvani K. Ubiquitin-like (UBX)-domain-containing protein, UBXN2A, promotes cell death by interfering with the p53-Mortalin interactions in colon cancer cells. Cell death \& disease. 2014; 5:e1118.

36. Shahbazi J, Scarlett CJ, Norris MD, Liu B, Haber M, Tee AE, Carrier A, Biankin AV, London WB, Marshall GM, Lock RB and Liu T. Histone deacetylase 2 and N-Myc reduce p53 protein phosphorylation at serine 46 by repressing gene transcription of tumor protein 53-induced nuclear protein 1. Oncotarget. 2014; 5:4257-4268. doi: 10.18632/oncotarget.1991.

37. Zhang HH, Li SZ, Zhang ZY, Hu XM, Hou PN, Gao L, Du RL and Zhang XD. Nemo-like kinase is critical for p53 stabilization and function in response to DNA damage. Cell death and differentiation. 2014; 21:1656-1663.

38. Fiori ME, Barbini C, Haas TL, Marroncelli N, Patrizii M, Biffoni M and De Maria R. Antitumor effect of miR-197 targeting in p53 wild-type lung cancer. Cell death and differentiation. 2014; 21:774-782.

39. Fortunato O, Boeri M, Moro M, Verri C, Mensah M, Conte D, Caleca L, Roz L, Pastorino U and Sozzi G. Mir-660 is downregulated in lung cancer patients and its replacement inhibits lung tumorigenesis by targeting MDM2-p53 interaction. Cell death \& disease. 2014; 5:e1564.

40. Giovannini C, Minguzzi M, Baglioni M, Fornari F, Giannone F, Ravaioli M, Cescon M, Chieco P, Bolondi L and Gramantieri L. Suppression of p53 by Notch3 is mediated by Cyclin G1 and sustained by MDM2 and miR221 axis in hepatocellular carcinoma. Oncotarget. 2014; 5:10607-10620. doi: 10.18632/oncotarget.2523.

41. Hoffman Y, Bublik DR, Pilpel Y and Oren M. miR-661 downregulates both Mdm2 and Mdm4 to activate p53. Cell death and differentiation. 2014; 21:302-309.

42. Ren ZJ, Nong XY, Lv YR, Sun HH, An PP, Wang F, Li $\mathrm{X}$, Liu $\mathrm{M}$ and Tang H. Mir-509-5p joins the Mdm2/p53 feedback loop and regulates cancer cell growth. Cell death \& disease. 2014; 5:e1387.

43. Soutto M, Chen Z, Saleh MA, Katsha A, Zhu S, Zaika A, Belkhiri A and El-Rifai W. TFF1 activates p53 through down-regulation of miR-504 in gastric cancer. Oncotarget. 2014; 5:5663-5673. doi: 10.18632/oncotarget.2156.

44. Zhang C, Liu J, Wang X, Wu R, Lin M, Laddha SV, Yang Q, Chan CS and Feng Z. MicroRNA-339-5p inhibits colorectal tumorigenesis through regulation of the MDM2/ p53 signaling. Oncotarget. 2014; 5:9106-9117. doi: 10.18632/oncotarget.2379.
45. Marcel V, Fernandes K, Terrier O, Lane DP and Bourdon JC. Modulation of p53beta and p53gamma expression by regulating the alternative splicing of TP53 gene modifies cellular response. Cell death and differentiation. 2014; 21:1377-1387.

46. Slatter TL, Hung N, Bowie S, Campbell H, Rubio C, Speidel D, Wilson M, Baird M, Royds JA and Braithwaite AW. Delta122p53, a mouse model of Delta133p53alpha, enhances the tumor-suppressor activities of an attenuated p53 mutant. Cell death \& disease. 2015; 6:e1783.

47. Becker MS, Schmezer P, Breuer R, Haas SF, Essers MA, Krammer PH and Li-Weber M. The traditional Chinese medical compound Rocaglamide protects nonmalignant primary cells from DNA damage-induced toxicity by inhibition of p53 expression. Cell death \& disease. 2014; 5:e1000,

48. Cheng J, Fan YH, Xu X, Zhang H, Dou J, Tang Y, Zhong X, Rojas Y, Yu Y, Zhao Y, Vasudevan SA, Zhang H, Nuchtern JG, Kim ES, Chen X, Lu F, et al. A smallmolecule inhibitor of UBE2N induces neuroblastoma cell death via activation of $\mathrm{p} 53$ and JNK pathways. Cell death $\&$ disease. 2014; 5:e1079.

49. Idogawa M, Ohashi T, Sugisaka J, Sasaki Y, Suzuki H and Tokino T. Array-based genome-wide RNAi screening to identify shRNAs that enhance p53-related apoptosis in human cancer cells. Oncotarget. 2014; 5:7540-7548. doi: 10.18632/oncotarget.2272.

50. Landre V, Rotblat B, Melino S, Bernassola F and Melino G. Screening for E3-Ubiquitin ligase inhibitors: challenges and opportunities. Oncotarget. 2014; 5:7988-8013. doi: 10.18632/oncotarget.2431.

51. Rossi M, Rotblat B, Ansell K, Amelio I, Caraglia M, Misso G, Bernassola F, Cavasotto CN, Knight RA, Ciechanover A and Melino G. High throughput screening for inhibitors of the HECT ubiquitin E3 ligase ITCH identifies antidepressant drugs as regulators of autophagy. Cell death \& disease. 2014; 5:e1203.

52. Yi L, Sun Y and Levine A. Selected drugs that inhibit DNA methylation can preferentially kill p53 deficient cells. Oncotarget. 2014; 5:8924-8936. doi: 10.18632/ oncotarget. 2441.

53. Zhuang C, Sheng C, Shin WS, Wu Y, Li J, Yao J, Dong G, Zhang W, Sham YY, Miao Z and Zhang W. A novel drug discovery strategy: mechanistic investigation of an enantiomeric antitumor agent targeting dual p53 and NFkappaB pathways. Oncotarget. 2014; 5:10830-10839. doi: 10.18632/oncotarget.2521.

54. Weilbacher A, Gutekunst M, Oren M, Aulitzky WE and van der Kuip H. RITA can induce cell death in p53-defective cells independently of p53 function via activation of JNK/ SAPK and p38. Cell death \& disease. 2014; 5:e1318.

55. Zhang X, Cheng L, Minn K, Madan R, Godwin AK, Shridhar V and Chien J. Targeting of mutant p53-induced FoxM1 with thiostrepton induces cytotoxicity and enhances carboplatin sensitivity in cancer cells. Oncotarget. 2014; 
5:11365-11380. doi: 10.18632/oncotarget.2497.

56. Yu X, Blanden AR, Narayanan S, Jayakumar L, Lubin D, Augeri D, Kimball SD, Loh SN and Carpizo DR. Small molecule restoration of wildtype structure and function of mutant p53 using a novel zinc-metallochaperone based mechanism. Oncotarget. 2014; 5:8879-8892. doi: 10.18632/ oncotarget. 2432.

57. Adamovich Y, Adler J, Meltser V, Reuven N and Shaul Y. AMPK couples p73 with p53 in cell fate decision. Cell death and differentiation. 2014; 21:1451-1459.

58. Amelio I, Antonov AA, Catani MV, Massoud R, Bernassola F, Knight RA, Melino G and Rufini A. TAp73 promotes anabolism. Oncotarget. 2014; 5:12820-12934. doi: 10.18632/oncotarget. 2667.

59. Bunjobpol W, Dulloo I, Igarashi K, Concin N, Matsuo K and Sabapathy K. Suppression of acetylpolyamine oxidase by selected AP-1 members regulates DNp73 abundance: mechanistic insights for overcoming DNp73-mediated resistance to chemotherapeutic drugs. Cell death and differentiation. 2014; 21:1240-1249.

60. D’Alessandro A, Amelio I, Berkers CR, Antonov A, Vousden KH, Melino G and Zolla L. Metabolic effect of TAp63alpha: enhanced glycolysis and pentose phosphate pathway, resulting in increased antioxidant defense. Oncotarget. 2014; 5:7722-7733. doi: 10.18632/ oncotarget.2300.

61. Fatt MP, Cancino GI, Miller FD and Kaplan DR. p63 and $\mathrm{p} 73$ coordinate $\mathrm{p} 53$ function to determine the balance between survival, cell death, and senescence in adult neural precursor cells. Cell death and differentiation. 2014; 21:1546-1559.

62. Kostecka A, Sznarkowska A, Meller K, Acedo P, Shi Y, Mohammad Sakil HA, Kawiak A, Lion M, Krolicka A, Wilhelm M, Inga A and Zawacka-Pankau J. JNK-NQO1 axis drives TAp73-mediated tumor suppression upon oxidative and proteasomal stress. Cell death \& disease. 2014; 5:e1484.

63. Yallowitz AR, Alexandrova EM, Talos F, Xu S, Marchenko ND and Moll UM. p63 is a prosurvival factor in the adult mammary gland during post-lactational involution, affecting PI-MECs and ErbB2 tumorigenesis. Cell death and differentiation. 2014; 21:645-654.

64. Burnley P, Rahman M, Wang H, Zhang Z, Sun X, Zhuge $\mathrm{Q}$ and $\mathrm{Su} \mathrm{DM}$. Role of the p63-FoxN1 regulatory axis in thymic epithelial cell homeostasis during aging. Cell death \& disease. 2013; 4:e932.

65. Salah Z, Bar-mag T, Kohn Y, Pichiorri F, Palumbo T, Melino $G$ and Aqeilan RI. Tumor suppressor WWOX binds to DeltaNp63alpha and sensitizes cancer cells to chemotherapy. Cell death \& disease. 2013; 4:e480.

66. Wu J, Liang S, Bergholz J, He H, Walsh EM, Zhang Y and Xiao ZX. DeltaNp63alpha activates CD82 metastasis suppressor to inhibit cancer cell invasion. Cell death \& disease. 2014; 5:e1280.
67. Agostini M, Niklison-Chirou MV, Catani MV, Knight RA, Melino G and Rufini A. TAp73 promotes anti-senescenceanabolism not proliferation. Aging(Albany NY). 2014; 6:921-930.

68. Amelio I, Cutruzzola F, Antonov A, Agostini M and Melino G. Serine and glycine metabolism in cancer. Trends in biochemical sciences. 2014; 39:191-198.

69. Amelio I and Melino G. The p53 family and the hypoxia-inducible factors (HIFs): determinants of cancer progression. Trends in biochemical sciences. 2015; 40:425434.

70. He Z, Liu H, Agostini M, Yousefi S, Perren A, Tschan MP, Mak TW, Melino G and Simon HU. p73 regulates autophagy and hepatocellular lipid metabolism through a transcriptional activation of the ATG5 gene. Cell death and differentiation. 2013; 20:1415-1424.

71. Inoue S, Tomasini R, Rufini A, Elia AJ, Agostini M, Amelio I, Cescon D, Dinsdale D, Zhou L, Harris IS, Lac S, Silvester J, Li WY, Sasaki M, Haight J, Brustle A, et al. TAp73 is required for spermatogenesis and the maintenance of male fertility. Proceedings of the National Academy of Sciences of the United States of America. 2014; 111:1843-1848.

72. Melino G, Memmi EM, Pelicci PG and Bernassola F. Maintaining epithelial stemness with p63. Science signaling. 2015; 8:re9.

73. Memmi EM, Sanarico AG, Giacobbe A, Peschiaroli A, Frezza V, Cicalese A, Pisati F, Tosoni D, Zhou H, Tonon G, Antonov A, Melino G, Pelicci PG and Bernassola F. p63 Sustains self-renewal of mammary cancer stem cells through regulation of Sonic Hedgehog signaling. Proceedings of the National Academy of Sciences of the United States of America. 2015; 112:3499-3504.

74. Viticchie G, Agostini M, Lena AM, Mancini M, Zhou H, Zolla L, Dinsdale D, Saintigny G, Melino G and Candi E. p63 supports aerobic respiration through hexokinase II. Proceedings of the National Academy of Sciences of the United States of America. 2015; 112:11577-11582.

75. Candi E, Agostini M, Melino G and Bernassola F. How the TP53 family proteins TP63 and TP73 contribute to tumorigenesis: regulators and effectors. Human mutation. 2014; 35:702-714.

76. Du W, Jiang P, Mancuso A, Stonestrom A, Brewer MD, Minn AJ, Mak TW, Wu M and Yang X. TAp73 enhances the pentose phosphate pathway and supports cell proliferation. Nature cell biology. 2013; 15:991-1000.

77. Amelio I, Inoue S, Markert EK, Levine AJ, Knight RA, Mak TW and Melino G. TAp73 opposes tumor angiogenesis by promoting hypoxia-inducible factor 1alpha degradation. Proceedings of the National Academy of Sciences of the United States of America. 2015; 112:226-231.

78. Moll UM and Slade N. p63 and p73: roles in development and tumor formation. Molecular cancer research. 2004; 2:371-386

79. Deyoung MP and Ellisen LW. p63 and p73 in human 
cancer: defining the network. Oncogene. 2007; 26:51695183.

80. Meyer G, Cabrera Socorro A, Perez Garcia CG, Martinez Millan L, Walker N and Caput D. Developmental roles of p73 in Cajal-Retzius cells and cortical patterning. The Journal of neuroscience. 2004; 24:9878-9887.

81. Yang A, Walker N, Bronson R, Kaghad M, Oosterwegel M, Bonnin J, Vagner C, Bonnet H, Dikkes P, Sharpe A, McKeon F and Caput D. p73-deficient mice have neurological, pheromonal and inflammatory defects but lack spontaneous tumours. Nature. 2000; 404:99-103.

82. Talos F, Abraham A, Vaseva AV, Holembowski L, Tsirka SE, Scheel A, Bode D, Dobbelstein M, Bruck W and Moll UM. p73 is an essential regulator of neural stem cell maintenance in embryonal and adult CNS neurogenesis. Cell death and differentiation. 2010; 17:1816-1829.

83. Wilhelm MT, Rufini A, Wetzel MK, Tsuchihara K, Inoue S, Tomasini R, Itie-Youten A, Wakeham A, ArsenianHenriksson M, Melino G, Kaplan DR, Miller FD and Mak TW. Isoform-specific p73 knockout mice reveal a novel role for delta Np73 in the DNA damage response pathway. Genes \& development. 2010; 24:549-560.

84. Tomasini R, Tsuchihara K, Tsuda C, Lau SK, Wilhelm M, Ruffini A, Tsao MS, Iovanna JL, Jurisicova A, Melino $\mathrm{G}$ and Mak TW. TAp73 regulates the spindle assembly checkpoint by modulating BubR1 activity. Proceedings of the National Academy of Sciences of the United States of America. 2009; 106:797-802.

85. Tomasini R, Tsuchihara K, Wilhelm M, Fujitani M, Rufini A, Cheung CC, Khan F, Itie-Youten A, Wakeham A, Tsao MS, Iovanna JL, Squire J, Jurisica I, Kaplan D, Melino G, Jurisicova A, et al. TAp73 knockout shows genomic instability with infertility and tumor suppressor functions. Genes \& development. 2008; 22:2677-2691.

86. Wager M, Guilhot J, Blanc JL, Ferrand S, Milin S, Bataille B, Lapierre F, Denis S, Chantereau T, Larsen CJ and Karayan-Tapon L. Prognostic value of increase in transcript levels of Tp73 DeltaEx2-3 isoforms in low-grade glioma patients. British journal of cancer. 2006; 95:1062-1069.

87. Kamiya $M$ and Nakazato $Y$. The expression of p73, p21 and MDM2 proteins in gliomas. Journal of neuro-oncology. 2002; 59:143-149.

88. Ugur H, Sayan AE, Ozdamar SO, Kanpolat Y and Ozturk M. Expression of TAP73 and DeltaNP73 in malignant gliomas. Oncology reports. 2004; 11:1337-1341.

89. Agostini M, Tucci P, Chen H, Knight RA, Bano D, Nicotera P, McKeon F and Melino G. p73 regulates maintenance of neural stem cell. Biochemical and biophysical research communications. 2010; 403:13-17.

90. Killick R, Niklison-Chirou M, Tomasini R, Bano D, Rufini A, Grespi F, Velletri T, Tucci P, Sayan BS, Conforti F, Gallagher E, Nicotera P, Mak TW, Melino G, Knight RA and Agostini M. p73: a multifunctional protein in neurobiology. Molecular neurobiology. 2011; 43:139-146.
91. Lee J, Kotliarova S, Kotliarov Y, Li A, Su Q, Donin NM, Pastorino S, Purow BW, Christopher N, Zhang W, Park JK and Fine HA. Tumor stem cells derived from glioblastomas cultured in bFGF and EGF more closely mirror the phenotype and genotype of primary tumors than do serumcultured cell lines. Cancer cell. 2006; 9:391-403.

92. Lee JK, Joo KM, Lee J, Yoon Y and Nam DH. Targeting the epithelial to mesenchymal transition in glioblastoma: the emerging role of MET signaling. OncoTargets and therapy. 2014; 7:1933-1944.

93. Aybar MJ, Nieto MA and Mayor R. Snail precedes slug in the genetic cascade required for the specification and migration of the Xenopus neural crest. Development. 2003; 130:483-494.

94. Antonov AV. BioProfiling.de: analytical web portal for high-throughput cell biology. Nucleic acids research. 2011; 39(Web Server issue):W323-327.

95. Friedl $\mathrm{P}$ and Alexander S. Cancer invasion and the microenvironment: plasticity and reciprocity. Cell. 2011; 147:992-1009.

96. Mikheev AM, Mikheeva SA, Trister AD, Tokita MJ, Emerson SN, Parada CA, Born DE, Carnemolla B, Frankel S, Kim DH, Oxford RG, Kosai Y, Tozer-Fink KR, Manning TC, Silber JR and Rostomily RC. Periostin is a novel therapeutic target that predicts and regulates glioma malignancy. Neuro-oncology. 2015; 17:372-382.

97. Zhou W, Ke SQ, Huang Z, Flavahan W, Fang X, Paul J, Wu L, Sloan AE, McLendon RE, Li X, Rich JN and Bao S. Periostin secreted by glioblastoma stem cells recruits M2 tumour-associated macrophages and promotes malignant growth. Nature cell biology. 2015; 17:170-182.

98. Morra L and Moch H. Periostin expression and epithelialmesenchymal transition in cancer: a review and an update. Virchows Archiv. 2011; 459:465-475.

99. Takeshita S, Kikuno R, Tezuka K and Amann E. Osteoblastspecific factor 2: cloning of a putative bone adhesion protein with homology with the insect protein fasciclin I. The Biochemical journal. 1993; 294 :271-278.

100. Horiuchi K, Amizuka N, Takeshita S, Takamatsu H, Katsuura M, Ozawa H, Toyama Y, Bonewald LF and Kudo A. Identification and characterization of a novel protein, periostin, with restricted expression to periosteum and periodontal ligament and increased expression by transforming growth factor beta. Journal of bone and mineral research. 1999; 14:1239-1249.

101. Liu AY, Zheng $\mathrm{H}$ and Ouyang G. Periostin, a multifunctional matricellular protein in inflammatory and tumor microenvironments. Matrix biology. 2014; 37:150156.

102. Malanchi I, Santamaria-Martinez A, Susanto E, Peng H, Lehr HA, Delaloye JF and Huelsken J. Interactions between cancer stem cells and their niche govern metastatic colonization. Nature. 2012; 481:85-89.

103. Kyutoku M, Taniyama Y, Katsuragi N, Shimizu H, 
Kunugiza Y, Iekushi K, Koibuchi N, Sanada F, Oshita Y and Morishita R. Role of periostin in cancer progression and metastasis: inhibition of breast cancer progression and metastasis by anti-periostin antibody in a murine model. International journal of molecular medicine. 2011; 28:181186.

104. Puglisi F, Puppin C, Pegolo E, Andreetta C, Pascoletti G, D’Aurizio F, Pandolfi M, Fasola G, Piga A, Damante G and Di Loreto C. Expression of periostin in human breast cancer. Journal of clinical pathology. 2008; 61:494-498.

105. Takanami I, Abiko $\mathrm{T}$ and Koizumi S. Expression of periostin in patients with non-small cell lung cancer: correlation with angiogenesis and lymphangiogenesis. The International journal of biological markers. 2008; 23:182186.

106. Hong LZ, Wei XW, Chen JF and Shi Y. Overexpression of periostin predicts poor prognosis in non-small cell lung cancer. Oncology letters. 2013; 6:1595-1603.

107. Ben QW, Zhao Z, Ge SF, Zhou J, Yuan F and Yuan YZ. Circulating levels of periostin may help identify patients with more aggressive colorectal cancer. International journal of oncology. 2009; 34:821-828.

108. Li Z, Zhang X, Yang Y, Yang S, Dong Z, Du L, Wang L and Wang $C$. Periostin expression and its prognostic value for colorectal cancer. International journal of molecular sciences. 2015; 16:12108-12118.

109. Sablina AA, Chumakov PM and Kopnin BP. Tumor suppressor p53 and its homologue p73alpha affect cell migration. The Journal of biological chemistry. 2003; 278:27362-27371.

110. Zhang Y, Yan W, Jung YS and Chen X. Mammary epithelial cell polarity is regulated differentially by $\mathrm{p} 73$ isoforms via epithelial-to-mesenchymal transition. The Journal of biological chemistry. 2012; 287:17746-17753.

111. Pont LM, Balvers RK, Kloezeman JJ, Nowicki MO, van den Bossche W, Kremer A, Wakimoto H, van den Hoogen BG, Leenstra S, Dirven CM, Chiocca EA, Lawler SE and Lamfers ML. In vitro screening of clinical drugs identifies sensitizers of oncolytic viral therapy in glioblastoma stemlike cells. Gene therapy. 2015; 22:947-5.

112. Hu Q, Tong S, Zhao X, Ding W, Gou Y, Xu K, Sun C and Xia G. Periostin Mediates TGF-beta-Induced Epithelial Mesenchymal Transition in Prostate Cancer Cells. Cellular physiology and biochemistry. 2015; 36:799-809.

113. Liu Y and Liu BA. Enhanced proliferation, invasion, and epithelial-mesenchymal transition of nicotinepromoted gastric cancer by periostin. World journal of gastroenterology. 2011; 17:2674-2680.

114. Sayan AE, Paradisi A, Vojtesek B, Knight RA, Melino G and Candi E. New antibodies recognizing p73: comparison with commercial antibodies. Biochemical and biophysical research communications. 2005; 330:186-193.

115. Agostini M, Tucci P, Steinert JR, Shalom-Feuerstein R, Rouleau M, Aberdam D, Forsythe ID, Young KW, Ventura
A, Concepcion CP, Han YC, Candi E, Knight RA, Mak TW and Melino G. microRNA-34a regulates neurite outgrowth, spinal morphology, and function. Proceedings of the National Academy of Sciences of the United States of America. 2011; 108:21099-21104.

116. Muller PA, Caswell PT, Doyle B, Iwanicki MP, Tan EH, Karim S, Lukashchuk N, Gillespie DA, Ludwig RL, Gosselin P, Cromer A, Brugge JS, Sansom OJ, Norman JC and Vousden KH. Mutant p53 drives invasion by promoting integrin recycling. Cell. 2009; 139:1327-1341.

117. Niklison-Chirou MV, Steinert JR, Agostini M, Knight RA, Dinsdale D, Cattaneo A, Mak TW and Melino G. TAp73 knockout mice show morphological and functional nervous system defects associated with loss of p75 neurotrophin receptor. Proceedings of the National Academy of Sciences of the United States of America. 2013; 110:18952-18957.

118. Cartharius K, Frech K, Grote K, Klocke B, Haltmeier M, Klingenhoff A, Frisch M, Bayerlein $M$ and Werner T. MatInspector and beyond: promoter analysis based on transcription factor binding sites. Bioinformatics. 2005; 21:2933-2942.

119. Amelio I, Gostev M, Knight RA, Willis AE, Melino G and Antonov AV. DRUGSURV: a resource for repositioning of approved and experimental drugs in oncology based on patient survival information. Cell death \& disease. 2014; 5:e1051.

120. Celardo I, Grespi F, Antonov A, Bernassola F, Garabadgiu AV, Melino G and Amelio I. Caspase-1 is a novel target of p63 in tumor suppression. Cell death \& disease. 2013; 4:e645.

121. Antonov A, Agostini M, Morello M, Minieri M, Melino $\mathrm{G}$ and Amelio I. Bioinformatics analysis of the serine and glycine pathway in cancer cells. Oncotarget. 2014; 5:1100411013. doi: 10.18632/oncotarget.2668. 